\title{
From Heroes to Saints and from Martyrological to Hagiographical Discourse*
}

\author{
Jan N. Bremmer
}

In 1889, Hermann Usener (1834-1905) published his most famous work, "Das Weihnachtsfest". At the time, he was one of Germany's leading classicists and the most prominent historian of ancient Greek and Roman religion, working with a particular focus on mythology. ${ }^{1}$ His book, which has not yet been replaced as a study of the origin of Christmas, was the first that analysed a Christian festival as if it was just like a pagan Roman celebration. In other words, it was the first that studied a major Christian feast not from a theological perspective but from a purely historical point of view. ${ }^{2}$

However, Usener's interest was not just historical. He was deeply committed to purifying the Christian Church of his day, in particular the Roman Catholic one, from its pagan survivals in order to build a church that would unite all Germans, both Protestants and Roman Catholics. To that end, Usener also studied the lives of saints, such as Tychon, Marina and Pelagia, in search of pagan antecedents. ${ }^{3}$ Given his great influence, it is not surprising that some of his pupils also claimed that the early Christian saints either performed the same function as the ancient Greek cultic heroes or had even developed from this cultic context. ${ }^{4}$ At the beginning of the $20^{\text {th }}$ century, anthropologists and historians of re-

* This contribution is the fruit of my stay as Visiting Professor at the Collaborative Research Center / Sonderforschungsbereich 948, Freiburg im Breisgau, September to December 2014. I am most grateful to Andreas Friedrich for making my stay in Freiburg so very enjoyable, and to audiences in Freiburg (2014), Cracow (2015), Sydney (Macquarie University), Erfurt and Bergen (2016), Bochum, Ghent, Frankfurt, Graz and Cologne (2017) for interesting discussions. I am also much indebted for clarifying comments to Jitse Dijkstra, Ton Hilhorst, Ralf von den Hoff (on $\S 1$ ), and Marc van Uytfanghe.

1 For Usener, see most recently J. N. Bremmer, Hermann Usener, in: W. W. Briggs / W. M. Calder III (ed.), Classical Scholarship: A Biographical Encyclopedia (Garland Reference Library of the Humanities; 928), New York 1990, p. 462-478 (with previous bibliography); M. Espagne / P. Rabault-Feuerhahn (ed.), Hermann Usener und die Metamorphosen der Philologie (Kultur- und sozialwissenschaftliche Studien; 7), Wiesbaden 2011.

2 H. Usener, Religionsgeschichtliche Untersuchungen. Erster Teil: Das Weihnachtsfest, Bonn 1889; cf. F. Pariente, Das Weihnachtsfest, in: A. Momigliano [et al.] (ed.), Aspetti di Hermann Usener filologo della religion, Pisa 1982, p. 181-211, here p. 211. Recently, though, Usener's work has been more critically discussed, cf. C. P. E. Nothaft, The Origins of the Christmas Date: Some Recent Trends in Historical Research, in: Church History 81, Issue 4, 2012, p. 903-911.

3 See his letter to Ignaz von Doellinger in H.-J. Mette, Nekrolog einer Epoche: Hermann Usener und seine Schule, in: Lustrum 22, 1979/80, p. 5-106, here p. 65, cf. Bremmer, Hermann Usener (Fn. 1), p. 469-470.

4 G. Wobbermin, Religionsgeschichtliche Studien, Berlin 1896, p. 18: "Die Heiligen der christlichen Kirchen, vor allem die der griechischen Kirche, stellen die gerade Fortentwick- 
ligion, under the influence of E. B. Tylor (1844-1917), considered belief in the soul and the cult of the dead to be a, if not the, origin of religion. It was natural, therefore, that the early cult of the saints was also seen as a continuation of the ancient cult of the dead. ${ }^{5}$ However, the suggestion of continuity between pagan heroes and Christian saints was not accepted by everybody. Already in 1905 the Jesuit and Bollandist Hippolyte Delehaye (1859-1941) had published a study, "Les légendes hagiographiques", in which he strongly contested these claims, as he would continue to do throughout his long and productive life. ${ }^{6}$ Looking back, it is not strange that Delehaye reacted quickly since the claims of the Protestant scholars struck at the heart of the doctrines and practices of the Roman Catholic Church. In the end, however, his own views came dangerously close to those of the Protestants and prohibition of his book by the Church was only averted through the intervention of the Belgian State. ${ }^{7}$

Subsequently, only one other great Roman Catholic scholar of hagiography, André-Jean Festugière (1898-1982), paid much attention to the Greek cultic hero, writing about the topic in his small book on sanctity published in 1949. ${ }^{8}$ Half a century later, however, increasing specialisation has meant that neither patristic nor Late Antique scholars of saints and sanctity look at the possible pagan

lung des griechischen Heroenkults dar. Die Heiligen sind die Heroen der Antike. Der Vergleich liesse sich im Einzelnen aufs genaueste durchführen". L. Deubner, De incubatione capita quatuor, Leipzig 1900, p. 57: "Christianorum quoque religio habebat atque habet suos semideos, suos heroas; sanctos scilicet martyresque". (On the same page Deubner thanks Usener: "cuius consilio omnino valde me adiutum esse grato profiteor animo".) E. Lucius, Die Anfänge des Heiligenkults in der christlichen Kirche, ed. by G. Anrich, Tübingen 1904, p. 14-48; P. Saintyves, Les saints successeurs des dieux, Paris 1907; further bibliography: W. Speyer, Heros, in: E. Dassmann [et al.] (ed.), Reallexikon für Antike und Christentum, Vol. 14: Heilig - Hexe, Stuttgart 1988, p. 861-877, here p. 873-875; E. Zocca, Modelli-Martirio-Santità: un rapporto multidirezionale, Adamantius 14, 2008, p. 378-394, here p. 378-379.

5 Lucius, Anfänge (Fn. 4), p. 14-34. For Tylor, see most recently A. Ciattini, L'animismo di Edward Burnett Tylor, Turin 1995; G. Stocking, Delimiting Anthropology, Madison, WI 2001, p. 103-146; E. Sera-Shriar, The Making of British Anthropology, 1813-1871 (Science and Culture in the Nineteenth Century; 18), London 2013, p. 147-176.

6 See also H. Delehaye, Les origines du culte des martyrs (Subsidia hagiographica; 20), Brussels ${ }^{2} 1933$, p. 24-26, although with the unpersuasive argument that "un culte, aussi essentiellement païen dans son esprit et dans ses rites, ne pouvait inspirer aux fidèles que des sentiments de réprobation" (ibid., p. 26).

7 Cf. R. Aubert, Le Père H. Delehaye et le Cardinal Mercier, in: Analecta Bollandiana 100, 1982, p. 743-780. For Delehaye, see T. Heffernan, Hippolyte Delehaye (1859-1941), in: H. Damico [et al.] (ed.), Medieval Scholarship, 3 Vols., New York 1995-2000, Vol 2: Literature and Philology, p. 215-227; B. Joassart, Hippolyte Delehaye (1859-1941): Un bollandiste au temps de la crise moderniste, in: L. Barmann / C. Talar (ed.), Sanctity and Secularity during the Modernist Period (Subsidia hagiographica; 79), Brussels 1999, p. 145; B. Joassart, Hippolyte Delehaye. Hagiographie critique et modernisme, 2 Vols. (Subsidia hagiographica; 81), Brussels 2000.

8 A.-J. Festugière, La sainteté (Mythes et religions; 9), Paris ${ }^{2} 1949$, p. $27-68$. 
roots of early Christian sainthood in detail any longer," at least not beyond the connections with the pagan holy men of Late Antiquity. On the contrary, the path-breaking studies of Peter Brown, for instance, have concentrated on the position of saints and 'holy men' in their own societies, albeit with a certain neglect of their spiritual side $(\S 2) .{ }^{10}$ Similarly, the equally important, but less widely received, studies of the Belgian early medievalist Marc Van Uytfanghe have focused on what he calls 'the hagiographical discourse' (§ 4).

The Greek word herôs, the ancestor of the modern word 'hero', has a double meaning. On the one hand, it denotes our hero, German Held, ${ }^{11}$ but, on the other, it also refers to a class of semi-divine beings between gods and mortals, whose sphere of influence was often restricted to the immediate area of their graves. Both, often interrelated, meanings can be found in connection with the early Christian martyrs, who according to the general consensus were the protosaints. Augustine had already noted that if ecclesiastical usage had not forbidden it, the martyrs could have been called 'our heroes', ${ }^{12}$ as they conquered the pagan heroes who lived in the air (like demons). Even so, his contemporary Prudentius gave the title Romanus, acris heros excellentiae to one of his hymns on a martyr ("Peristephanon" 10.52), clearly exploiting the secular meaning of the word. ${ }^{13}$ Indeed, in one of our oldest surviving reports of a persecution, the Letter of the congregations of Vienne and Lyons to those in Asia and Phrygia, probably dating to AD 177, the martyrs are described as "sturdy pillars that could by their endurance take on themselves all the attacks of the Evil One” (1.6, tr. H. Musurillo, The Acts of the Christian Martyrs, Oxford 1972). Their martyrdom

9 But see P. Brown, The Cult of the Saints. Its Rise and Function in Latin Christianity (Haskell Lectures on History of Religions; New Series 2), Chicago/London 1981, p. 5-6; C. P. Jones, New Heroes in Antiquity (Revealing Antiquity; 18), Cambridge, MA/London 2010, p. 84-85.

10 As was argued by two Roman Catholic scholars: J. Fontaine, Le culte des saints et ses implications sociologiques, réflexions sur un récent essai de P. Brown, in: Analecta Bollandiana 100, 1982, p. 17-42, and Ch. Pietri, Christiana Respublica, 3 Vols. (Collection de L'Ecole Française de Rome; 234), Rome 1997, Vol. 2, p. 1207-1233. Note the reaction of Brown in the "Preface to the 2014 Edition" of the new edition of his "The Cult of the Saints": P. Brown, The Cult of the Saints. Its Rise and Function in Latin Christianity (Haskell Lectures on History of Religions; New Series 2), Chicago 22015, p. xx-xxiii.

11 For etymologies of Indo-European terms for hero, also Held, see G.-J. Pinault, Une nouvelle connexion entre le substrat indo-iranien et le tokharien commun, in: Historische Sprachforschung 116, Issue 2, 2003, p. 175-189; A. L. Lloyd / R. Lühr, Etymologisches Wörterbuch des Althochdeutschen, Vol. 4: gâba - hylare, Göttingen 2009, p. $938-939$ (Held).

12 Augustine, De Civitate Dei 10.21, cf. J. den Boeft, Some Etymologies in Augustine's De Civitate Dei X, in: Vigiliae Christianae 33, Issue 3, 1979, p. 242-259, here p. 250-252. Augustine's airy heroes (aeriae potestates) derive from Varro, cf. Arnobius $3.41=$ Varro, Ant. fr. 209 Cardauns; Augustine, De Civitate Dei 7.6 = Varro, Ant. fr. 226 Cardauns, but the idea was also present in the East, cf. D. A. Russell / N. G. Wilson, Menander Rhetor, Oxford 1981, p. 162, §414.5-6.

13 For other examples, see H. Kornhardt, 'beros', in: Thesaurus Linguae Latinae 6, Leipzig 1934, p. 2661-2666, here p. 2664.14-22. 
was "the greatest of all the wars which they waged against the Devil" (2.6). Evidently, the martyrs were the heroic defenders against the attacks of the Devil on the Church; they were the militia Dei. ${ }^{14}$

In my contribution I would like to return to the debate that flourished as the $19^{\text {th }}$ century turned into the $20^{\text {th }}$ and look at the roots of Christian sainthood and its first developments. ${ }^{15}$ As the Greek cultic heroes became conceptualised as a class in the later sixth century BC, we will look at nearly a millennium of ancient religious history and end our study around $\mathrm{AD} 400$, when the saints are becoming well established. In the course of my investigation I will pay attention to terminological, geographical, chronological, social and religious aspects of the rise of sainthood. Admittedly, the literature on the subject is enormous. That is why I will concentrate on the scholarly discussions of recent decades and, naturally, will limit myself to the main lines. Nevertheless, in this way we may perhaps acquire a somewhat more nuanced view of the rise of an influential, and nearly two-millennia-old, class of religious heroes: the Christian saints. Let us start with the Greek cultic heroes.

\section{From Heroes to Zeroes}

The Greek word ท๊ $\rho \omega \varsigma$ (bêrôs) derives from a pre-Greek language, and its original meaning is still unclear. ${ }^{16}$ Our oldest source, Homer, often uses the word for the collective of the Greeks or Trojans but also uses it for single warriors, all of whom lived before the present generation of mortals. The term is not used for females (the Greek word for 'heroine' is fairly late) or for gods. Moreover, in Homer and his younger contemporaries, the term is never used to denote a cultic hero. ${ }^{17}$ How, then, do we explain this development of a separate category of cultic heroes?

Walter Burkert (1931-2015) took a step in the right direction when he suggested that the rise of the hero cult should not be separated from the restructur-

14 Tertullian, De oratione 19: militia Dei sumus; Cyprian, Epistula 58, cf. J. W. van Henten, The Martyrs as Heroes of the Christian People. Some Remarks on the Continuity between Jewish and Christian Martyrology, with Pagan Analogies, in: M. Lamberigts / P. Van Deun (ed.), Martyrium in Multidisciplinary Perspective (Ephemerides theologicae Lovanienses, Bibliotheca; 117), Leuven 1995, p. 303-322.

15 I am of course much indebted to the excellent surveys by Th. Baumeister, Heiligenverehrung I, in: E. Dassmann [et al.] (ed.), Reallexikon für Antike und Christentum, Vol. 14: Heilig - Hexe, Stuttgart 1988, p. 96-150, and M. Van Uytfanghe, L'origine, l'essor et les fonctions du culte des saints. Quelques repères pour un débat rouvert, in: Cassiodorus 2, 1996, p. 143-196.

16 For its pre-Greek etymology, see R. Beekes, Etymological Dictionary of Greek, 2 Vols. (Leiden Indo-European Etymological Dictionary Series; 10.1-2), Leiden 2010, Vol. 1, p. 526.

17 See the careful survey of F. Horn, Held und Heldentum bei Homer (Classica Monacensia; 47), Tübingen 2014, p. 10-30 (with earlier bibliography). 
ing of spiritual life under the influence of Homer, although Burkert assigned too early a date to this development. ${ }^{18}$ The gradual emergence of the heroes as a class coincides with the first mention of the group of twelve Olympian gods on Lesbos around $600 \mathrm{BC}$ and in Athens around $520 \mathrm{BC} .{ }^{19}$ Around $500 \mathrm{BC}$ we can observe a growing awareness of the difference between gods and their statues, and this period also gives us Xenophanes' (B14-16 Diels/Kranz) famous attack on divine anthropomorphism and Heraclitus' (B 5 Diels/Kranz) ridiculing of those who "pray to the statues here as if one were chattering with houses, not recognizing what gods or even heroes are like". ${ }^{20}$ Evidently, a hardening of the division between the main gods of the Greeks and all other (for lack of a better word!) supernatural beings worthy of worship took place in the course of the later sixth century BC, the latter now finally and definitively being classified as 'heroes'. In other words, heroes as 'purely' cultic figures became firmly established only in the course of the sixth century BC. The mixture of Homer's heroes, ancestor cults and belief in the powerful dead was the pre-history of this final stage, but there cannot have been a proper hero cult any earlier since the category simply had not been conceptualised before the sixth century. ${ }^{21}$

18 W. Burkert, Greek Religion, Oxford 1985, p. 205; see also his "L'eroizzazione": W. Burkert, L'eroizzazione, in: L. Abbondanza [et al.] (ed.), Apoteosi da uomini a dei, Rome 2014, p. 20-27.

19

Lesbos: Alcaeus, fr. 349e Voigt/Liberman, cf. J. N. Bremmer, The Greek Gods in the Twentieth Century, in: J. N. Bremmer / A. Erskine (ed.), The Gods of Ancient Greece (Edinburgh Leventis Studies; 5), Edinburgh 2010, p. 1-18, here p. 6; I. Rutherford, Canonizing the Pantheon: the Dodekatheon in Greek Religion and its Origins, in: J. N. Bremmer / A. Erskine (ed.), The Gods of Ancient Greece (Edinburgh Leventis Studies; 5), Edinburgh 2010, p. 43-54. Athens: Thucydides 6.54.6, see, most recently, S. Georgoudi, Les Douze dieux des Grecs: variations sur un thème, in: S. Georgoudi / J.-P. Vernant (ed.), Mythes grecs au figuré: de l'antiquité au baroque, Paris 1996, p. 43-80; S. Georgoudi, Les Douze Dieux et les autres dans l'espace cultuel grec, in: Kernos 11, 1998, p. 73-83; R. W. Johnston / D. Mulroy, The Hymn to Hermes and the Athenian Altar of the Twelve Gods, in: The Classical World 103, Issue 1, 2009, p. 3-16.

20 For the statues, see J. N. Bremmer, The Agency of Greek and Roman Statues: from Homer to Constantine, in: Opuscula 6, 2013, p. 7-21, here p. 8-9 (with previous bibliography on gods and their statues).

21 Similarly: J. J. Bravo III, Recovering the Past: The Origins of Greek Heroes and Hero Cult, in: S. Albersmeier (ed.), Heroes: Mortals and Myths in Ancient Greece, Baltimore 2009, p. 10-29, here p. 17, although overlooking my article with the same conclusion (below). As Burkert, Greek Religion (Fn. 18), p. 205, notes: "if the concept and cult form were established at a relatively late date [...] then this does not exclude the reception of very ancient traditions in the new complex". I have summarized, updated and slightly revised here my "The Rise of the Hero Cult and the New Simonides" (J. N. Bremmer, The Rise of the Hero Cult and the New Simonides, in: Zeitschrift für Papyrologie und Epigraphik 158, 2006, p. 15-26), which is not refuted by N. Himmelmann, Der ausruhende Herakles, Paderborn 2009, p. 190-192, and R. Parker, On Greek Religion (Cornell Studies in Classical Philology; 60), Ithaca, NY/London 2011, p. 287-292. A. Brelich, Gli eroi greci (Nuovi saggi; 21), Rome 1958, is still the indispensable and most original study of the earlier heroes. The fullest survey of the hero-cult now is K. Buraselis [et al.], Heroisierung und Apotheose, in: Thesaurus Cultus et Rituum Antiquorum, Vol. 2, Los Angeles 2004, p. 125-214, here p. 126-158, to be added to Jones, New Heroes in Antiquity (Fn. 9), and my 2006 article; 
The late emergence of the category bêrôs perhaps explains the difficulty of modern scholars in finding a difference between the sacrificial rituals in honour of heroes and those honouring the gods. In fact, contemporary studies increasingly stress that there are no significant differences..$^{22}$ As there was no independent authority to decide who belonged where, some heroes, most famously Heracles and Achilles, remained hovering on the edge of the divine. In any case, the landscape of the Greek world now came to be awash with local heroes and, albeit to a much lesser extent, heroines, ${ }^{23}$ whose bones were occasionally even kidnapped in order to enhance the status or protection of a city. ${ }^{24}$ The centre of the cult was the grave of the hero, which was sometimes situated in the centre of the city, the agora. ${ }^{25}$ However, it seems to fit the gradual and late development of the cult that there was no standardized form for their sanctuaries, the bêrôa. ${ }^{26}$

note also Speyer, Heros (Fn. 4). For the Forschungsgeschichte, see the brief but excellent survey by R. Gordon, Hero-cults, Old and New, in: Journal of Roman Archaeology 26, 2013, p. $852-860$, here p. $852-854$.

22 G. Ekroth, The Sacrificial Rituals of Greek Hero-Cults in the Archaic to the Early Hellenistic Periods (Kernos, Supplément; 12), Liège 2002; R. Hägg / B. Alroth (ed.), Greek Sacrificial Ritual, Olympian and Chthonian, Stockholm 2005; R. Parker, Polytheism and Society at Athens, Oxford 2005, p. 446.

23 Most recently: E. Kearns, The Heroes of Attica (Bulletin of the Institute of Classical Studies, Supplement; 57), London 1989, and E. Kearns, Between God and Man. Status and Function of Heroes and Their Sanctuaries, in: A. Schachter / J. Bingen (ed.), Le sanctuaire grec (Entretiens sur l'Antiquité Classique; 37), Geneva 1992, p. 65-99; J. Larson, Greek Heroine Cults, Madison, WI 1995; D. Lyons, Gender and Immortality. Heroines in Ancient Greek Myth and Cult, Princeton 1997; R. Hägg (ed.), Ancient Greek Hero Cult, Jonsered 1999; V. Pirenne-Delforge / E. Suárez de la Torre (ed.), Héros et héroïnes dans les mythes et les cultes grecs (Kernos, Supplément; 10), Liège 2000; G. Ekroth, Heroes and Hero-Cults, in: D. Ogden (ed.), A Companion to Greek Religion, Oxford 2007, p. 100114; S. Albersmeier (ed.), Heroes: Mortals and Myths in Ancient Greece, Baltimore 2009; Himmelmann, Der ausruhende Herakles (Fn. 21); F. Neri, Reliquie eroiche nella Grecia arcaica e classica (VI-IV sec. A. C.) (Istituto Italiano per gli Studi Storici; 58), Bologna 2010; Parker, On Greek Religion (Fn. 21), p. 103-123; G. Salapata, Laconian and Messenian Plaques with Seated Figures: The Socio-Political Dimension, in: The Annual of the British School at Athens 108, 2013, p. 187-200; G. Salapata, Heroic Offerings. The Terracotta Plaques from the Spartan Sanctuary of Agamemnon and Kassandra, Ann Arbor 2014.

Most recently: C. Higbie, The Bones of a Hero, the Ashes of a Politician: Athens, Salamis, and the Usable Past, in: Classical Antiquity 16, Issue 2, 1997, p. 278-307; B. McCauley, The Transfer of Hippodameia's Bones: A Historical Context, in: The Classical Journal 93, Issue 3, 1998, p. 225-239; M. Fell, Kimon und die Gebeine des Theseus, in: Klio 86, Issue 1, 2004, p. 16-54; B. R. Doak, The Fate and Power of Heroic Bones and the Politics of Bone Transfer in Ancient Israel and Greece, in: Harvard Theological Review 106, Issue 2, 2013, p. 201-216.

25 See, most recently, H. Schörner, Sepulturae graecae intra urbem. Untersuchungen zum Phänomen der intraurbanen Bestattungen bei den Griechen, Möhnesee 2007; A. Herda, Burying a Sage: The Heroon of Thales in the Agora of Miletos, in O. Henry (ed.), Le mort dans la ville, Istanbul 2013, p. 67-122.

26 For the varied nature of the sanctuaries, see H. Abramson, Greek Hero-Shrines, Diss. Berkeley, 1978: non vidi; D. Damaskos [et al.], Kultorte und Kultbauten, in: Thesaurus Cultus et Rituum Antiquorum, Vol. 2 (Fn. 21), p. 152-158; A. Seiffert, Heroon, in: Thesaurus Cultus et Rituum Antiquorum, Vol. 4, Los Angeles 2005, p. 24-38; M. Mikkola, 
The first heroes were the warriors of the Trojan War and, somewhat later, the founders of Greek colonies. Yet, and this is an important difference with the later saints, earlier heroes could be malicious as well as benevolent and could send all kinds of diseases to ravage mortals. This dual character comes through clearly in the chorus of Aristophanes' "Heroes": "we are the guardians of good things and ill; we watch out for the unjust, for robbers and footpads, and send them diseases - spleen, coughs, dropsy, catarrh, scab, gout, madness, lichens, swellings, ague, fever. That's what we give to thieves." 27 The same ambiguous nature is also noted by a character in one of Menander's plays: "The heroes are keener at doing harm than at helping out" (F 322 Kassel/Austin). This negative side of heroes disappeared, though, in the course of the Hellenistic period.

The positive aspects of heroes were expressed in many different ways and functions, reflecting their varied origin. Heroes were closely associated with the gymnasium and gymnastic games were held in their honour, such as the Trophoneia of Lebadeia or the Amphiaraia of Oropos. The latter were in honour of Amphiaraos, one of the Seven against Thebes, who also had an oracle in Oropos, just like Melampus in Megara. Other heroes were closely associated with incubation and healing sanctuaries, such as Asclepius in Epidaurus or Cheiron in Demetrias. Some were linked to Mysteries, such as Eurytos in Andania and the Dioscures on Samothrace, who were also invoked by those in peril on the sea, whereas Theseus and Heracles were connected to rites of initiation. The secret grave of a hero could be a talisman of the city, as in the case of Oedipus, but it could also be the ancestor of political divisions, as was the case with the heroes of the 10 phylai of Athens. There were even heroes connected with heralds, such as the Spartan hero Thaltybios, with priestly families, such as the Eleusinian Eumolpos, with seers, such as Iamos, or with doctors, such as Asclepius on Cos. In other words, heroes were omnipresent in the Greek world because of their myths, rituals and sanctuaries. ${ }^{28}$

If we set aside older traditions, such as the cult of ancestors, we can see that in the beginning the military nature of heroes was paramount and they were often

Heroa as Described in the Ancient Written Sources, in: L. Pietilä-Castrén / V. Vahtikari (ed.), Grapta Poikila, Vol. 2 (Papers and Monographs of the Finnish Institute at Athens; 14), Helsinki 2008, p. 1-32; L. Pietilä-Castrén, A Methodological Note on "Rectangular heroa", in: L. Pietilä-Castrén / V. Vahtikari (ed.), Grapta Poikila, Vol. 2 (Papers and Monographs of the Finnish Institute at Athens; 14), Helsinki 2008, p. 33-48.

27 Aristophanes fr. 322 Kassel/Austin, translated and commented upon by R. Parker, Miasma. Pollution and Purification in Early Greek Religion, Oxford 1983, p. 243-244; Babrius, Fables 63.7-12; Athenaeus 11.461C; cf. M. García Tejeiro / M. T. Molinos Tejada, Les héros méchants, in: V. Pirenne-Delforge / E. Suárez de la Torre (ed.), Héros et hérö̈nes dans les mythes et les cultes grecs (Kernos, Supplément; 10), Liège 2000, p. 111-123; V. Liapis, Ghosts, wand'ring here and there: Orestes the Revenant in Athens, in: V. Liapis / D. Cairns (ed.), Dionysalexandros, Swansea 2006, p. 201-231.

28 For these and many more examples, see Brelich, Gli eroi greci (Fn. 21), p. 79-185. 
represented armed with their weapons, although this feature is absent in the early Spartan hero-reliefs. ${ }^{29}$ This tradition had a long life: it can be seen in the heroisation of generals and outstanding warriors, such as Brasidas, Aratus and Philopoemen, and in the fact that heroic epiphanies would assist worshippers in defeating their enemies during times of crisis - a tradition lasting well into the First World War, albeit with saints like St George replacing the ancient heroes. ${ }^{30}$ In addition, also athletes and Olympic victors such as Euthymos, ${ }^{31}$ famous poets such as Homer and Archilochus, ${ }^{32}$ and philosophers like Epicurus and the charismatic Apollonius of Tyana became heroised in the course of time..$^{33}$

A relaxing of the borders between gods and mortals is noticeable in the Hellenistic period, in particular, probably due to the intensification of the ruler cult after Alexander the Great. In literature this development becomes notably visible in Apollonius of Rhodes' epic "Argonautica", whereas in inscriptions we see it happening from about 200 BC. ${ }^{34}$ In Roman times, Greek magnates who had negotiated favourable terms for their cities with the Romans or had saved their cities in the years of the Roman Civil War in the first century BC, 35 were heroised, as were other city leaders. These developments exemplify the reduction in the importance of military qualities over time as moral virtues started to take their place, ${ }^{36}$ a development that should also be taken into account in the rise of the saints. Elite families could now build a hêrôon for their deceased members, especially their patriarchs and those sons who had died young. ${ }^{37}$ Given their status, it is not surprising that these graves were usually built in the centre of the city. ${ }^{38}$

29 Cf. Aristophanes fr. 240, Adespota fr. 948 Kassel/Austin; F. T. van Straten, Did the Greeks Kneel before their Gods?, in: Bulletin Antieke Beschaving 49, 1974, p. 159-189, here p. 187-189.

30 J. N. Bremmer, Greek Religion and Culture, the Bible and the Ancient Near East (Jerusalem Studies in Religion and Culture; 8), Leiden 2008, p. 215-217.

31 F. Bohringer, Cultes d'athlètes en Grèce antique, in: Revue des Études Anciennes 81, 1979, p. 5-18; B. Currie, Euthymos of Locri. A Case Study in Heroization in the Classical Period, in: The Journal Hellenic Studies 122, 2002, p. 24-44.

32 D. Clay, Archilochus Heros. The Cult of Poets in the Greek Polis (Hellenic Studies; 6), Washington, D.C. 2004.

33 B. Currie, Pindar and the Cult of Heroes, Oxford 2005; Jones, New Heroes (Fn. 9), p. 38-47.

34 Inscriptiones Graecae XII 3, 330 (Thera: testament of Epicteta); J. Fabricius, Zwischen Konvention und Tabu. Zum Umgang mit Heroenehrungen in hellenistischen Poleis, in: M. Meyer / R. von den Hoff (ed.), Helden wie sie. Übermensch - Vorbild - Kultfigur in der griechischen Antike (Rombach Wissenschaften, Reihe Paradeigmata; 13), Freiburg im Breisgau 2010, p. 257-293; S. Hitch, Hero Cult in Apollonius Rhodius, in: M. A. Harder [et al.] (ed.), Gods and Religion in Hellenistic Poetry (Hellenistica Groningana; 16), Leuven 2012, p. 131-162.

35 See now P. Fröhlich, Funérailles publiques et tombeaux monumentaux intra-muros dans les cités grecques à l'époque hellénistique, in: M.-C. Ferriès / M. P. Castiglioni (ed.), Forgerons, élites et voyageurs d'Homère à nos jours, Grenoble 2013, p. 227-309.

36 Gordon, Hero-cults (Fn. 21), p. 857; F. Graf, Nordionische Kulte (Bibliotheca Helvetica Romana; 21), Rome 1985, p. 132-133.

37 For the young age of the Late Antique new heroes, see ibid., p. 131, 135.

38 Ibid., p. 133. 
Women and daughters rarely received this honour, although there were exceptions, such as Regilla, the wife of the Athenian magnate Herodes Atticus, who died ca. AD 157.39 Although such a heroisation was certainly a sign of status and prestige, people also expected benefactions from these new heroes, who could even appear in dreams. ${ }^{40}$ As less and less illustrious citizens, albeit none from the very lowest orders, were called 'hero' after their death without any notable achievements to their credit, the zeroes of my title, so distinctly average tombs could also be called hêrôa, a custom even attested among Phrygian Christians in the third century. ${ }^{41}$

This development, which differed in its details from place to place and from island to island, stops being recorded in the middle of the third century; an inscription of AD 242 is the last one known to mention the honouring of a citizen as a hero..$^{42}$ The date can hardly be separated from the decline of the epigraphic habit but heroes also disappear from literature at this time. It is probably not by chance that only a few decades at the most before that date, the sophist Philostratus wrote a dialogue called "Heroikos", 'Heroic Discourse', in which the hero cult is discussed. The literary nature of the work makes it difficult to deduce precisely the author's own view of that cult, whether affirmative or skeptical, but the date of composition, probably in the $\mathrm{AD} 220 \mathrm{~s},{ }^{43}$ seems to fit a time of receding interest in the cult of the heroes, even though a cult lasted well into the fourth century in some places. ${ }^{44}$

In conclusion, at the time of the rise of Christianity there was a widespread custom in the Eastern part of the Mediterranean to call civic leaders and the deceased young of the higher classes 'hero', whereas, through literature and material manifestations such as hêrôa, the cult of heroes remained well known to all educated Greeks. ${ }^{45}$ On the other hand, the Romans did not have such an intermediate category of supernatural beings. ${ }^{46}$ We should therefore be attentive to a possible difference between East and West in the rise of the cult of the saints.

39 Inscriptiones Graecae XIV 1389 = Inscriptiones Graecae Urbis Romae 11558f (AD 161), cf. Supplementum Epigraphicum Graecum 29.999.

40 Graf, Nordionische Kulte (Fn. 36), p. 128-131; C. P. Jones, A "New Hero" at Attea (Mysia), in: Zeitschrift für Papyrologie und Epigraphik 192, 2014, p. 156-158; C. P. Jones, An Altar for a New Hero, in: Zeitschrift für Papyrologie und Epigraphik 192, 2014, p. 183-186.

41 Jones, New Heroes (Fn. 9), p. 64; Monumenta Asiae Minoris Antiqua (MAMA) 6.224.

42 Inscriptiones Graecae XII.7, $53^{34 f}$.

43 For the date, see Philostratus, Heroicus, Gymnasticus, Discourses 1 and 2, ed. and transl. by J. Rusten / J. König, Cambridge, MA/London 2014, p. 10.

44 For the gradual disappearance of the pagan heroes, see Jones, New Heroes (Fn. 9), p. 88-92.

45 On the famous heroes at schools and in philosophy, see A. Gangloff, Les héros et les penseurs grecs des deux premiers siècles après J.-C.: mythologie et éducation, in: Pallas 78, 2008, p. 153-168.

46 The contrary view of B. Liou-Gille, Cultes "héroiques" romains. Les fondateurs, Paris 1980, has not been accepted. 


\section{How Holy is Holy?}

In his seminal 1971 article on the holy man, ${ }^{47}$ Peter Brown paid little or no attention to the earlier history of the term 'holy' or the roots of the phenomenon of what he calls the 'holy man'.48 Nor did he give the usage and origin of the term 'saint' much attention in his well-known study of the cult of the saints. ${ }^{49}$ Modern reputable scholars also speak of pagan 'holy men' or 'pagan saints' (§ 4), as if these are fully comparable with Christian holy men and saints. ${ }^{50}$ Yet it does not seem immediately helpful to apply Christian terminology to pagan figures without further reflection on the suitability of this language. Does the difference in religion really make no difference for the usage? In addition, many students of early Christian saints also use the term without reflecting on whether this is emic or etic usage. For a proper study of the beginning of sainthood we should, I think, ask ourselves when the early Christians started to call certain persons 'saints' or 'holy' and what they meant by those terms? And as we have noted the absence of heroes in the West, so we should also ask if there was a difference in the terminology of the holy between the Eastern and Western parts of the Roman Empire.

Originally, the Greeks had two words: hagnos and, especially, bieros, which we translate as 'sacred' or 'holy'. ${ }^{51}$ Hagnos is an adjective used to indicate the reverence due to divinities, the inviolable sanctity of places, such as sanctuaries, and activities, such as a dance in divine service, although it also indicates the purity of the worshipper who thus expresses his reverence for the gods or their domain. ${ }^{52}$ Hieros was the word used for everything to do with gods and sanctuaries:

47 P. Brown, The Rise and Function of the Holy Man in Late Antiquity, in: The Journal of Roman Studies 61, 1971, p. 80-101, reprinted in P. Brown, Society and the Holy in Late Antiquity, London 1982, p. 103-152. Note also the important retrospective article by P. Brown, The Rise and Function of the Holy Man in Antiquity, 1971-1997, in: Journal of Early Christian Studies 6, Issue 3, 1998, p. 353-376.

As is well observed by A. Louth, Holiness and Sanctity in the Early Church, in: P. Clarke / T. Claydon (ed.), Saints and Sanctity (Studies in Church History; 47), Woodbridge 2011, p. 1-18.

49 Cf. Brown, Cult of the Saints (Fn. 9), p. 1-22.

50 G. Fowden, The Pagan Holy Man in Late Antique Society, in: The Journal of Hellenic Studies 102, 1982, p. 33-59; J. Elsner, Beyond Compare: Pagan Saint and Christian God in Late Antiquity, in: Critical Enquiry 35, Issue 3, 2009, p. 655-683.

51 For the Greek vocabulary of the sacred, see Parker, Miasma (Fn. 27), p. 147-150; A. Motte, L'expression du sacré dans la religion grecque, in: J. Ries (ed.), L'expression du sacré dans les grandes religions, Vol. 3 (Homo religiosus; 3), Louvain-la-neuve 1986, p. 109-256; A. Dihle, Heilig, in: E. Dassmann [et al.] (ed.), Reallexikon für Antike und Christentum, Vol. 14: Heilig - Hexe, Stuttgart 1988, p. 1-63, here p. 1-16; A. Dihle, Ausgewählte kleine Schriften zu Antike und Christentum (Jahrbuch für Antike und Christentum, Ergänzungsband; 38), Münster 2013, p. 373-388; S. Peels, Hosios: A Semantic Study of Greek Piety (Mnemosyne, Supplementum; 387), Leiden, 2015.

52 Parker, Miasma (Fn. 27), p. 147-151; Burkert, Greek Religion (Fn. 18), p. 17 (bagnos). 
a priest is a biereus, a sacrifice a bieron, and to sacrifice biereusthai. In short, to use Burkert's striking formulation, bieros is 'as it were the shadow cast by divinity'. ${ }^{53}$ As if this were not enough, around $500 \mathrm{BC}$ a new word, hagios, was introduced, which was used especially with regard to temples, rites and mysteries, indicating their high status and their ancient, venerable origin. ${ }^{54}$

In Rome, the central pre-Latin word for 'holy' is sacer. This is an extremely fertile word, the cognates of which occur in all kinds of Roman religious terms, such as sacerdos, sacramentum and sacrificare. The most important word in this respect is sancire, which means 'to render sacred'. Its participle sanctus acquired the meaning 'sanctified' and developed towards the meaning of 'holy' with the concomitant meaning 'pure, irreproachable', just like hagnos. Yet sanctus always keeps the meaning of being sanctified by humans: one speaks of a mons sacer but a lex sancta. The unqualified meaning 'holy' is relatively late, and in the third century $\mathrm{AD}$ the great legal specialist Ulpian can still write: sancta quae neque sacra neque profana sunt sed sanctione quadam confirmata (Dig. 1.8.9)..$^{55}$

The pre-eminence of hieros and sacer in the pagan vocabulary of the sacred is emphasised by their absence from Jewish and Christian vocabulary. When the Jews started to translate the Old Testament into Greek they purposely chose hagios for the Hebrew kadosh and mostly avoided hieros, which was evidently considered to be too much of a terminus technicus of Greek religion, ${ }^{56}$ and they were followed by the Christians in this respect. For the same reason, Tertullian, the first Christian author for whom we have a large corpus of Latin texts, rejected sacer in favour of sanctus, just as Jerome did in the Vulgate. ${ }^{57}$

53 Parker, Miasma (Fn. 27), p. 51-52, 328-331 (verbs); Burkert, Greek Religion (Fn. 18), p. 269; J. L. García Ramón, Griechisch bieros und seine Varianten, vedisch isirá, in: R. Beekes [et al.] (ed.), Rekonstruktion und relative Chronologie (Innsbrucker Beiträge zur Sprachwissenschaft, Vorträge und kleinere Schriften; 65), Innsbruck 1992, p. 183-205.

54 J. Nuchelmans, À propos de hagios avant l'époque hellénistique, in: A. A. R. Bastiaensen [et al.] (ed.), Fructus centesimus. Mélanges G. J. M. Bartelink (Instrumenta Patristica; 19), Steenbrugge/Dordrecht 1989, p. 239-258.

55 H. Fugier, Recherches sur l'expression du sacré dans la langue latine (Publication de la Faculté des Lettres de Strasbourg; 146), Strasbourg 1963; M. Morani, Lat. "sacer" e il rapporto uomo-dio nel lessico religioso latino, in: Aevum 55, Issue 1, 1981, p. 30-46; J.-C. Fredouille, Les écrivains et le sacré à Rome, in: Actes du XII ${ }^{\mathrm{e}}$ Congrès de l’Association Guillaume Budé, Paris 1989, p. 85-115; M. de Vaan, Etymological Dictionary of Latin and the other Italic Languages (Leiden Indo-European Etymological Dictionary Series; 7), Leiden 2008, p. 532 s.v. sacer.

56 T. Rajak, Translation \& Survival. The Greek Bible of the Ancient Jewish Diaspora, Oxford 22011, p. 165-166.

57 H. Delehaye, Sanctus. Essai sur le culte des saints dans l'antiquité (Subsidia Hagiographica; 17), Brussels 1927, p. 36; R. Braun, Approches de Tertullien (Collection des ètudes augustiniennes, Série antiquité; 134), Paris 1992, p. 273-286; E. Zocca, Dai "santi" al "Santo": un percorso storico linguistico intorno all'idea di santità (Africa Romana secc. II-V.) (Verba seniorum; 13), Rome 2003, p. 135-148. 
In our earliest Christian texts, the letters of Paul ("Romans" 1.7, 12.13, and so on), the word hagios is used only in the plural for Christ's followers. It expresses their participation in God's holiness but also their separation from the world. ${ }^{58}$ The Christians are a 'communion of saints' but there are no individual saints. The term also served as a self-designation, as we can see in the letter of Vienne to Lyons mentioned above ("Martyrium Lugduni" 1.4, 14). We find the same idea elsewhere in the West when, in the middle of the third century, Bishop Cyprian of Carthage ("Epistula" 59.19) called the Church of Rome the sanctissima plebs. At the same time, the collected bishops are called sanctissimi sacerdotes, but this usage may well have derived from the official nomenclature of the Romans, who called censors, emperors and high magistrates sanctissimus. ${ }^{59}$ This qualification was also taken over in the East with Alexander of Jerusalem, who probably lived during the rule of Caracalla, already calling living bishops hagioi. ${ }^{60}$

Yet there was also another, smaller group of Christians that was called hagios. The idea of calling martyrs hagioi must have originated among Greek Christians rather early on, since we already find this language in the "Acts of Justin" (A: 1 and 6) dated around AD 165; in Origen; ${ }^{61}$ and in the mention by Bishop Dionysius of Alexandria during the persecution of Decius (Eus. HE 6.41.18) of a 'bagia virgin' Ammonarion (note the Egyptian name) who was martyred for her faith. ${ }^{62}$

58 O. Proksch, hagios, etc., in: G. Friedrich (ed.), Theologisches Wörterbuch zum Neuen Testament, Teil 1: A-G, Stuttgart 1933, p. 87-116; W. Elert, Die Herkunft der Formel "Communio sanctorum”, in: Theologische Literaturzeitung 74, Issue 10, 1949, p. 577-586; R. Bauckham, The Holiness of Jesus and His Disciples in the Gospel of John, in: K. E. Brower / A. E. Johnson (ed.), Holiness and Ecclesiology in the New Testament, Grand Rapids, MI/Cambridge 2007, p. 95-113; M. Bohlen, Sanctorum communio. Die Christen als 'Heilige' bei Paulus (Zeitschrift für die neutestamentliche Wissenschaft, Beihefte; 183), Berlin/New York 2011.

59 Cf. Delehaye, Sanctus (Fn. 56), p. 4-5, 37-45; O. Hiltbrunner, Die Heiligkeit des Kaisers (Zur Geschichte des Begriffs sacer), in: Frühmittelalterliche Studien 2, 1968, p. 1-30; Zocca, Dai "santi" al "Santo" (Fn. 57), 238-239 (usage by Augustine).

60 West: W. von Hartel, S. Thasci Caecili Cypriani opera omnia, Vol. 1 (Corpus scriptorum ecclesiasticorum Latinorum; 3.1), Vienna 1868, p. 441, p. 446. East: Eusebius, Historia Ecclesiastica 6.19.18. Cf. E. Jerg, Vir venerabilis. Untersuchungen zur Titulatur der Bischöfe in den ausserkirchlichen Texten der Spätantike als Beitrag zur Deutung ihrer öffentlichen Stellung (Wiener Beiträge zur Theologie; 26), Vienna 1970. For the time of Alexander and Eusebius' use of his letter, see A. J. Carriker, The Library of Eusebius of Caesarea (Supplements to Vigiliae Christianae; 67), Leiden/Boston 2003, p. 181-182.

61 F. Faessler, Der Hagiosbegriff bei Origenes (Paradosis; 13), Fribourg 1958, p. 56-62.

62 The mention of Agathonice dying 'together with the saints' in the Greek version of the "Martyrdom of Carpus, Papylus and Agathonice" (47) is much later, cf. for the date of this martyrdom under Decius as well as the Greek and Latin versions, C. P. Jones, Notes on the Acta Carpi and Some Related Martyr-Acts, in: M. Cassia [et al.] (ed.), Pignora Amicitiae: Scritti di Storia antica e di Storiografia offerti a Mario Mazza, Rome 2012 [2014], p. 259268. The mention in the "Martyrdom of Pionius" (1) of sharing 'in the remembrances of the saints', is probably fourth-century, cf. O. Zwierlein, Die Urfassungen der Martyria Polycarpi et Pionii und das Corpus Polycarpianum, 2 Vols. (Untersuchungen zur antiken Literatur und Geschichte; 116.1-2), Berlin/Boston 2014, Vol. 2: Textgeschichte und Rekonstruktion. Polykarp, Ignatius und der Redaktor Ps.-Pionius, p. 70-72. 
The West soon seemed to have followed suit, as we already find the usage in Tertullian. ${ }^{63}$ Bishop Cyprian is even called sanctus martyr electus a Deo in the "Acts of Cyprian" (21.1 and $2^{2} .1$ Bastiaensen), which were written during the persecution under Valerian in AD 257 and 258. The bishop is also called sanctus Cyprianus $\left(2^{2} .5\right)$ but this is highly exceptional; in none of the cases of other martyrs do we hear of a 'holy X or Y'. Indeed, the text of the recensio altera in which this expression occurs is of a somewhat later date than the report of the events in AD 258. ${ }^{64}$ In any case, it is the following of Christ and dying for his cause that made them holy as a group. ${ }^{65}$ It is obvious that this is a holiness much different from that of the pagan 'holy men', to whom we will turn shortly (§ 4).

\section{Martyrological Discourse and Cult of the Martyrs}

As we noted in the Introduction, the martyrs are generally, and rightly, seen as the ancestors of the saints. We will therefore look at the martyrs and their possible cults before discussing the cult of the saints (§5). The prehistory of the term and concept 'martyr' has often been discussed and need not concern us here. ${ }^{66}$ Suffice it to say that Greek martys, 'witness', gradually developed into a term for somebody who had died for his faith in Christ, although the original connection with the meaning 'witness' was not wholly lost, as is shown by the end of the Latin version of the "Martyrdom of Carpus" (7: see note 62): martyrizaverunt autem testes Dei, 'martyred were God's witnesses'. The early Church must have considered the reports of these martyrdoms to be of considerable importance since we find a writer as early as Eusebius already mentioning his collection of 'the

63 Tertullian, De fuga 5.3; Passio Perpetuae 1.6 en 16.1; Cyprian, Epistulae 23 and 36.2, 3.

64 Cf. A. A. R. Bastiaensen [et al.], Atti e passioni dei martiri, Milan 1987, p. 202-204.

65 M. Van Uytfanghe, La typologie de la sainteté en Occident vers la fin de l'Antiquité, in: G. Luongo (ed.), Scrivere di santi. Atti del II Convegno di studio dell'Associazione italiana per lo studio della santità, dei culti e dell'agiografia, Rome 1998, p. 17-48, here p. 19, who also rightly points to the evolving concepts of holiness in early Christianity: there is not one fixed concept valid for all ages, but every age has its own ideas of holiness; P. Gemeinhardt, Die Kirche und ihre Heiligen (Studien und Texte zu Antike und Christentum; 90), Tübingen 2014, p. 71-98.

See the surveys by W. Rordorf, Martyre I, II, in: Dictionnaire de Spiritualité, Vol. 10: Mabille - Mythe, Paris 1980, p. 718-732; G. W. Bowersock, Martyrdom and Rome, Cambridge 1995, p. 1-21; E. Zocca, "Martiri" e "martirio" nella chiesa precostantiania, in: G. Malaguti (ed.), Martirio di pace. Memoria e storia del martirio nel XVII centenario di Vitale e Agricola, Bologna 2004, p. 259-278; J.W. van Henten, Martyrium II, in: G. Schöllgen [et al.] (ed.), Reallexikon für Antike und Christentum, Vol. 24: Manethon Montanismus, Stuttgart 2012, p. 300-325, here p. 302-316; Gemeinhardt, Die Kirche und ihre Heiligen (Fn. 64), p. 153-155. For the older bibliography, see T. Baumeister, Martyrium, Hagiographie und Heiligenverehrung im christlichen Altertum (Römische Quartalschrift für christliche Altertumskunde und Kirchengeschichte, Supplementband; 61), Freiburg im Breisgau 2009, p. 11. 
martyrdoms of the ancients', which dates from before ca. AD 295.67 Yet the modern study starts only in the sixteenth century, when the expression Acta martyrum was first used in the title of a book about Protestant martyrs and subsequently for a book of the early Christian martyrs. ${ }^{68}$

Although most early texts have disappeared, several descriptions of martyrdoms have survived that go back to the actual court reports, the so-called acta, which have also given their name to the modern genre. These reports were evidently available for inspection, as is demonstrated by a letter sent to Cyprian by his fellow bishops: 'As a good and true teacher you preceded us in declaring in the records of the official proceedings of the proconsul (apud acta proconsulis) what we, your pupils, treading in your footsteps ought to say before the governor' (Cyprian, Ep. 77.2.1). ${ }^{69} \mathrm{~A}$ more recently discovered letter of Augustine shows that he too could still read original transcripts, which he calls gesta forensia or publica gesta. In fact, he clearly preferred these unadorned protocols over the socalled 'epic passions', which we will discuss below $(\S 5) .{ }^{70}$ Initially, the accounts of martyrdoms constituted a heterogeneous corpus of texts. For example, the "Acta Scillitanorum" is basically the report of a court case; the already mentioned Letter of Lyons and Vienne is, as it says, a letter from one congregation to another; and the "Passion of Perpetua" is a combination of a diary, a report of a dream and editorial comments. Given this variety of origins, we should thus refrain from considering these early reports as a clearly defined genre.

Yet, despite their differences, the more authentic reports of the early Christian martyrdoms display enough similarities that we can speak of a martyrological discourse in the first centuries, which helped to promote the gradually develop-

67 Eusebius, Historia Ecclesiastica 4.15.47, 5. Praeparatio Evangelica, praef. 2, 5.4.3, 5.21.5; cf. V. Saxer, Les Actes des 'Martyrs anciens' chez Eusèbe de Césarée et dans les martyrologes syriaque et hiéronymien, in: Analecta Bollandiana 102, 1984, p. 85-95. Date: Zwierlein, Urfassungen, Vol. 2 (Fn. 61), p. 108.

68 J. Crispin, Acta martyrum ..., Geneva 1556. T. Ruinart, Acta primorum martyrum sincera \& selecta, Paris 1689 , is the first to use Acta martyrum as a book title for a collection of early Christian martyrdoms, cf. T. D. Barnes, Early Christian Hagiography and Roman History (Tria Corda; 5), Tübingen 2010, p. 295-297, 343.

69 Cf. Vita Cypriani 11.1: "et quid sacerdos Dei proconsule interrogante responderit, sunt acta quae referant"; note also the interesting case of Bishop Dionysius of Alexandria in Eusebius, Historia Ecclesiastica 7.11.3-11. For the accessibility of the legal archives, see B. Anagnostou-Canas, La documentation judiciaire pénale dans l'Égypte romaine, in: Mélanges de L'École française de Rome - Antiquité 112, Issue 2, 2000, p. 753-779; P. van Minnen, Saving History? Egyptian Hagiography in its Space and Time, in: J. Dijkstra / M. van Dijk (ed.), The Encroaching Desert. Egyptian Hagiography and the Medieval West (Church History and Religious Culture; 86), Leiden 2006, p. 57-91, here p. 60-62; Barnes, Early Christian Hagiography (Fn. 68), p. 54-66.

70 Augustine, Lettres $1 *-29 *$, ed. by J. Divjak [et al.], Paris 1987, Epistulae*. 29.1, 2, p. 414417, to be read with the commentary by Y. Duval, ibid., p. 573-580; C. Lepelley, Les réticences de saint Augustin face aux légendes hagiographiques d'après la lettre Divjak 29*, in: Ph. Rousseau / M. Papoutsakis (ed.), Transformations of Late Antiquity. Essays for Peter Brown, Farnham/Burlington 2009, p. 147-158. 
ing cult of the martyrs. The unity of this discourse results both from the background of the Acta martyrum in actual legal processes against the Christians and from the theological reflection on the martyrdoms. This combination expressed itself in three important themes which we find in most early Acta. First, the highpoint of the interrogation of the martyr was the confession: 'I am a Christian', which probably popularised the name of 'Christians' for followers of Christ. The confession was sufficient to condemn the Christian martyr to death and thus often the climax of the report of their processes. ${ }^{71}$ Secondly, and closely related to the first point, the martyrs and/or the authors of the reports of their executions stylised them(selves) as followers, sometimes even as imitators, of Christ: the martyr Blandina, for example, seemed to hang in the form of a cross when executed ("Martyrium Lugduni”" 41). ${ }^{72}$

Thirdly, persistence until the end was considered a victory over the Devil. Thus the opponent, usually the Roman judge, was seen as his manifestation. ${ }^{73}$ In the case of the "Passion of Perpetua and Felicitas" (10), the fight against Satan is even played out in a dream in which Perpetua conquers a black Egyptian - perhaps also a sign of the emotional preoccupation with the motif before her death. ${ }^{74}$ It is the combination of these themes that unites the various reports, even if it is only our modern perspective that has grouped the various reports together into a genre. Still, we always have to be conscious that these reports are not neutral accounts but are written with a purpose. They were produced and preserved as exempla for and of the moments of persecution. While the more

71 For a full collection of passages, see J. N. Bremmer, The Rise and Fall of the Afterlife, London/New York 2002, p. 105-108 (also about the origin of the name 'Christian'); add Acta Abitiniarum 5, 7, 10 and 13-18; P. Canart / R. Pintaudi, Il martirio di san Pansofio, in: Analecta Papyrologica 16-17, 2004-2005 [2007], p. 189-245, here p. 197 (c.3). The discussion of the confession by N. Hartmann, Martyrium. Variationen und Potenziale eines Diskurses im Zweiten Jahrhundert (Early Christianity in the Context of Antiquity; 14), Frankfurt am Main 2013, p. 137-142, is unpersuasive.

72 M. Pellegrino, Ricerche patristiche, 2 Vols., Turin 1982, Vol. 1, p. 385-703 passim; I. Kinnard, Imitatio Christi in Christian Martyrdom and Asceticism: A Critical Dialogue, in: O. Freiberger (ed.), Asceticism and Its Critics: Historical Accounts and Comparative Perspectives, Oxford 2006, p. 131-150; C. R. Moss, The Other Christs: Imitating Jesus in Ancient Christian Ideologies of Martyrdom, Oxford 2010; C. R. Moss, Ancient Christian Martyrdom: Diverse Practices, Theologies, and Traditions, New Haven/London 2012, p. 49-76. The theme will remain important in the later 'passions épiques' (§ 5): M. Taveirne, Das Martyrium als imitatio Christi: Die literarische Gestaltung der spätantiken Märtyrerakten und -passionen nach der Passion Christi, in: Zeitschrift für Antikes Christentum 18, Issue 2, 2014, p. 167-203.

73 See, for example, Martyrium Polycarpi 3.1 (although probably third-century if not later); Martyrium Lugduni 1.5, 6 etc.; Passio Perpetuae 10.14; Passio Lucii et Montani 6.4-5; Passio Fructuosi 7.2.

74 For a detailed analysis of this vision, see J. N. Bremmer, Perpetua and Her Diary: Authenticity, Family and Visions, in: W. Ameling (ed.), Märtyrer und Märtyrerakten (Altertumswissenschaftliches Kolloquium; 6), Stuttgart 2002, p. 77-120, here p. 112-119. 
authentic ones sometimes come close to being eye-witness reports, ${ }^{75}$ they always contain theological reflections and we often find literary embellishments as well. ${ }^{76}$

In this connection it is normal for scholars to speak of a cult of the martyrs. Yet we should perhaps be somewhat reticent about the notion. It is true that from the mid-third century onwards the early Christians in Carthage and Rome started to remember the day of death of their martyrs and even kept a kind of martyrological calendar. ${ }^{77}$ Yet an anniversary does not immediately constitute a cult, as is witnessed by the celebration of the birthdays of modern monarchs or the special days of remembrance for the dead who fell in the great wars of the last century. So which criteria should we apply when speaking of a cult? Delehaye notes the following aspects: the celebration of the anniversary of the martyr, a martyrological calendar, the concentration on the tomb of the martyr and appeals for intercession, ${ }^{78}$ to which I would add the invocation of the martyr (see below) and the worship of relics. ${ }^{79}$ The appearance of only one or two of these

75 For the incorporation of "a substantial amount of authentic material" in the Acta martyrum, see Bowersock, Martyrdom and Rome (Fn. 65), p. 23-39, here p. 38. T. Barnes, Early Christian Hagiography and the Roman Historian, in: P. Gemeinhardt / J. Leemans (ed.), Christian Martyrdom in Late Antiquity (300-450 AD). History and Discourse, Tradition and Religious Identity (Arbeiten zur Kirchengeschichte; 116), Berlin/Boston 2012, p. 1533, here p. 18-19, rightly takes L. Grig, Making Martyrs in Late Antiquity, London 2004, to task for suggesting the opposite.

76 See the illuminating discussion, also of the early history of the modern genre, by W. Wischmeyer, Märtyrerakten, in: H. D. Betz [et al.], Religion in Geschichte und Gegenwart, Vol. 5: L-M, Tübingen ${ }^{4}$ 2002, p. 873-875; H. R. Seeliger / W. Wischmeyer, Märtyrerliteratur. Herausgegeben, übersetzt, kommentiert und eingeleitet (Texte und Untersuchungen zur Geschichte der altchristlichen Literatur; 172), Berlin/München/Boston 2015, p. 1-45.

A. Stuiber, Heidnische und christliche Gedächtniskalender, in: Jahrbuch für Antike und Christentum 3, 1960, p. 24-33; Pietri, Christiana Respublica (Fn. 10), p. 1283-1288, who rightly notes that this remembering presupposes "l'initiative et le contrôle du clergé" (ibid., p. 1287).

Cf. Delehaye, Sanctus (Fn. 56), p. 123-124.

79 For the cult of the relics, see especially A. Angenendt, Heilige und Reliquien: Die Geschichte ihres Kultes vom frühen Christentum bis zur Gegenwart, Munich 21997; E. Bozóky, La politique des reliques de Constantin à Saint Louis, Paris 2006; P. Cortez, Die Reliquien, ein Forschungsfeld. Traditionslinien und neue Erkundungen, in: Kunstchronik 7, 2007, p. 271-282. For early relics, see A. Thacker, Rome of the Martyrs: Saints, Cults and Relics, Fourth to Seventh Centuries, in: É. Ó Carragáin / C. Neuman de Vegvar (ed.), Roma felix - Formation and Reflections of Medieval Rome (Church, Faith and Culture in the Medieval West; 10), Aldershot 2007, p. 13-49; R.M. Jensen, Saints' Relics and the Consecration of Church Buildings in Rome, in: Studia Patristica 71, 2014, p. 153-169. The case of the rich widow Lucilla, who kissed a martyr's bone before receiving the Eucharist, is an absolute exception and given too much weight by Brown, Cult of the Saints (Fn. 9), p. 34, cf. Optatus, Contra Parmenianum 1.16; R. Wiśniewski, Lucilla and the Bone. Remarks on an Early Testimony to the Cult of Relics, in: Journal of Late Antiquity 4, Issue 1, 2011, p. 157-161. Brown's other example of the "privatization of the holy" by noble families, the memoria in Salona, also does not hold up to scrutiny, cf. A. M. Yasin, Reassessing Salona's Churches: Martyrium Evolution in Question, in: Journal of Early Christian Studies 20, Issue 1, 2012, p. 59-112. 
aspects might suggest the beginning of a cult but hardly a cult proper. Unfortunately, Delehaye's own discussion does not systematically take account of time and place. ${ }^{80}$ So when and where do these factors become visible?

Until recently, the "Martyrdom of Polycarp" was adduced as the main witness for the nascent cult of the martyrs. Recent studies, however, have persuasively argued that the account as we have it is a later version of a sober second-century report, perhaps dating from the first edition of Eusebius' "Church History" ca. AD 307-312, which added the celebration of the anniversary of Polycarp's death at his grave. ${ }^{81}$ That leaves few authentic testimonies to the general persecutions in the time of Decius and Valerian, when we find the first certain indications of a developing cult in the West in North Africa, which is, not incidentally, also the area that has left us the greatest number of surviving early Acta martyrum. ${ }^{82}$

Visits to the resting places of martyrs are attested in the West from the time of Tertullian, ca. AD 200, who frequently mentions the yearly remembrances of the dead. ${ }^{83}$ The "Passion of Perpetua" also demonstrates the importance of the reports of the martyrdoms, its editor arguing that these deserve to be read during official worship. ${ }^{84}$ But that is all we know of a possible cult of the martyrs at the time of Tertullian, when the Christians mostly perpetuated their ancestral pagan funeral rites, although with new interpretations and representations. ${ }^{85}$ Yet the persecutions of the period around AD 200 seem to have made the Christians look back and wonder about the graves of the apostles and other early martyrs. If we want to fix a time for the beginning of the process of cultic worship it seems to have been the turn of the third century. ${ }^{86}$ In discussions of this aspect of the early cult of the martyrs, it is rarely pointed out that Jesus himself did not attach any value to a cult of the dead, as is shown by his words about letting the dead bury the dead (Matthew 8.22). Indeed, in the apocryphal "Acts of John" (84) and

80 Cf. Delehaye, Sanctus (Fn. 56), p. 122-161; Delehaye, Les origines (Fn. 6), p. 24-140.

81 C. Moss, On the Dating of Polycarp: Rethinking the Place of the Martyrdom of Polycarp in the History of Christianity, in: Early Christianity 1, Issue 4, 2010, p. 539-574; Zwierlein, Urfassungen, Vol. 2 (Fn. 61), p. 208-209.

82 See the survey in V. Saxer, Afrique Latin (jusqu'en 540), in: G. Philippart (ed.), Hagiographies, Turnhout 1994, Vol. 1, p. 25-96.

83 Tertullian, De corona 3.3, De exhortatione castitatis 11.1, De monogamia 10.4; V. Saxer, Morts martyrs reliques en Afrique chrétienne aux premiers siècles. Les témoignages de Tertullien, Cyprien et Augustin à la lumière de l'archéologie africaine (Théologie historique; 55), Paris 1980, p. 70-73.

84 Passio Perpetuae 1.6, 21.11, cf. J. den Boeft, The Editor's Prime Objective: Haec in Aedificationem Ecclesiae Legere, in: J. N. Bremmer / M. Formisano (ed.), Perpetua's Passions. Multidisciplinary Approaches to the Passio Perpetuae et Felicitatis, Oxford 2012, p. 169-179.

85 Saxer, Morts, martyrs, reliques (Fn. 82), p. 35-83; P.-A. Février, La Méditerranée, 2 Vols. (Collection de L'École Française de Rome; 225), Rome/Aix-en-Provence 1996, Vol. 1, p. 3-360. The new interpretations are stressed by S. Diefenbach, Römische Erinnerungsräume (Millennium-Studien; 11), Berlin/New York 2007, p. 38-80.

86 See the letter of Polycrates quoted by Eusebius, Historia Ecclesiastica 5.24.2-5, cf. Van Uytfanghe, L'origine, l'essor (Fn. 15), p. 156-157. 
those of "Peter" (40), both dating to the last decades of the second century and deriving from Asia Minor, funeral rites are still not considered to be very important. ${ }^{87}$ This moderate, if not negative, attitude towards the dead and their graves would last until the end of the persecutions (below), and it is only after Constantine that we start to find the equivalent of a herôon for martyrs: the martyrion. ${ }^{88}$

Half a century after Tertullian, a kind of martyrological calendar is mentioned at the time of Cyprian. The bishop, we learn, ordered his clergy to note down the days of the confessors - those that had died in prison before an actual martyrdom - among the days in which the martyrs are remembered (Ep. 12.2, 39.3). Yet this calendar can hardly have been much older, since the persecutions before Decius were incidental and certainly not widespread and systematic. Given that martyrs were initially remembered by their own congregation, ${ }^{89}$ such calendars will have been typical of the larger towns of the Roman Empire where we may suppose there to have been more martyrs. Moreover, Cyprian's insistence on the inclusion of confessors shows that he, as bishop, played an important role in the development of such a calendar. In the next half century after Cyprian's martyrdom the cult seems to have intensified in the West. ${ }^{90}$ In an oration to bishops and other prominent Christians, perhaps held in Trier in AD 314, ${ }^{91}$ Constantine himself mentions that there were hymns, psalms, prayers and the Eucharist for martyrs. ${ }^{92}$ His mention of pure light suggests that visits to the cemeteries traditionally began in the dark, that is, with a vigil, as we hear of later martyr festivals. In other words, it looks very much as if there is a cult in the West at this time, even if we do not yet hear of any relics. ${ }^{93}$

It is in the East that we find the first examples of an intercessory prayer by a kind of confessor and a martyr. ${ }^{94}$ In the apocryphal "Acts of Paul", which were

87 Cf. O. Zwierlein, Petrus in Rom. Die literarischen Zeugnisse (Untersuchungen zur antiken Literatur und Geschichte; 96), Berlin/New York 22010, p. 109-113 and O. Zwierlein, Petrus und Paulus in Jerusalem und Rom. Vom Neuen Testament zu den apokryphen Apostelakten (Untersuchungen zur antiken Literatur und Geschichte; 109), Berlin 2013, p. 28-29; W. Ameling, Petrus in Rom. Zur Genese frühchristlicher Erinnerung, in: S. Heid (ed.), Petrus und Paulus in Rom. Eine interdisziplinäre Debatte, Freiburg im Breisgau 2011, p. 468-491, here p. 481-484. This makes the exceptional case of the "Martyrdom of Polycarp" also improbable for the second century.

90 Baumeister, Heiligenverehrung I (Fn. 15), p. 118-122.

91 For date and place, see now K. Girardet, Konstantin, Rede an die Versammlung der Heiligen (Fontes Christiani; 55), Freiburg im Breisgau 2013, p. 36-44.

92 Constantine, Oratio ad sanctorum coetum, 12.4-5.

93 If the cult was already fully developed at Constantine's time, it makes the argument of R. Markus, The End of Ancient Christianity, Cambridge 1990, p. 90-95, that it bridged the time before and after Constantine less plausible.

94 Lucius, Anfänge (Fn. 4), p. 69-71; G. Jouassard, Le rôle des chrétiens comme intercesseurs auprès de Dieu dans la chrétienté Lyonnaise au second siècle, in: Revue des Sciences Religieuses 30, 1956, p. 217-229; E. Dassmann, Sündenvergebung durch Taufe, Buße und 
written in southern Asia Minor and date to about AD 189-200, the young girl Thecla, a dedicated follower of the apostle, prays for Falconilla, the late daughter of Queen Tryphaena, at the latter's request (29). Thecla is not a martyr but her situation as an arrested Christian makes her very similar to the Western confessors. ${ }^{95}$ Somewhat later, probably during the persecutions initiated by Septimius Severus, a soldier named Basilides declared that he had seen the Alexandrian martyr Potamiaena in a dream and was told that she had prayed that he would join her in her martyrdom (Eusebius, HE 6.5.6).

In the West we have the virtually contemporaneous case of Perpetua, who was martyred in AD 203. In her diary she relates that she was entitled to pray for her dead brother Dinocrates because her own death was imminent. ${ }^{96}$ Since Tertullian ("De baptismo" 17.5, written between AD 198 and 206) tells us that the "Acts of Paul" were read in Carthage by Christian women, Perpetua may well have been influenced by Thecla's example. The belief that martyrs and confessores could intercede on behalf of the deceased was indeed widespread, with Tertullian and Cyprian abundantly attesting to the custom in Carthage. ${ }^{97}$ It is remarkable that this belief seems to have arisen and been accepted almost simultaneously in the East and the West, surely a sign of the close communication between the various parts of the early Christian community. In all of these early cases, however, the intercessory power is ascribed to martyrs and confessors personally known to those who request their intercession. The invocation is not yet part of a cult of the martyrs. In the East, Eusebius (PE 13.11.2) also mentions visits to graves of the martyrs, whom he calls 'the soldiers of the true piety', with prayers and expressions of honour 'for their blessed souls', but our evidence does not yet mention special graves or great festivities at the graves in that part of the Empire.

If we now look back, we can conclude that martyrs were highly important for the early Christians, even if our evidence mainly derives from the West. Their deaths were remembered, friends and family could ask them for intercession, and the congregation probably tended their graves, as we can see by the fact that the emperor Valerian forbade meetings at cemeteries already in AD 257. ${ }^{98}$ However, we do not yet see the combination of factors that we have identified as indicative

Martyrerfürbitte in den Zeugnissen frühchristlicher Frömmigkeit und Kunst (Münsterische Beiträge zur Theologie; 36), Münster 1973, p. 153-182.

95 For a detailed discussion of this passage, see J. Trumbower, Rescue for the Dead. The Posthumous Salvation of Non-Christians in Early Christianity, New York 2001, p. 56-75.

96 Passio Perpetuae 7.2, cf. Bremmer, Perpetua and Her Diary (Fn. 73), p. 105-112.

97 Tertullian, Ad martyras 1.6, De pudicitia 22, Scorpiace 10.8; Cyprian, Epistulae. 15.1.2, 21.2.1 and 3.2, 27.1.1; Eusebius, Historia Ecclesiastica 5.1.45, 5.2.5, 5.18.6-7, 6.5.6. Cyprian (Epistula 21) mentions a certain Celerinus who writes to the confessor Lucianus for intercession on behalf of his sister who had died after she had lapsed, cf. Y. Duval, Celerinus et les siens d'après la correspondance de Cyprien (Ep. 21-23, 37, 39), in: Revue d'Études Augustiniennes et Patristiques 47, Issue 1, 2001, p. 33-62, here p. 52-59.

Acts of Cyprian 1.7; Eusebius, Historia Ecclesiastica 7.11.10. 
of a fully developed cult, let alone the labelling of individuals as 'saints' ${ }^{99}$ This situation would change with the victory of Constantine in AD 312 but before we discuss that development we will turn first to the pagan holy men.

\section{Pagan 'Holy Men' and the Hagiographical Discourse}

Following Peter Brown's seminal 1971 article on the rise and function of the Christian 'holy man', scholars immediately started to discover pagan 'holy men', although far fewer 'holy women'. ${ }^{100}$ In his authoritative 1982 study, Garth Fowden set out 'the distinctive pagan concept of personal holiness' (33). ${ }^{101}$ Fowden sees this holiness embodied in a combination of Platonic metaphysics and Pythagorean piety (38). The names here already indicate that it was almost only philosophers who were seen as pagan holy men (36), with the life of Pythagoras exerting an increasing influence on the biographies of these men in the course of Late Antiquity (36-37). ${ }^{102}$ Primarily, they were teachers of philosophy with a close circle of pupils (38-39), from prosperous backgrounds (49) and living in cities (39-40), who were gradually marginalised because of the increasing pressure put on paganism by the advance of Christianity (54-59).

The sphere of activity of these men was the great centres of Greek culture in the East, from Athens to Aphrodisias to Alexandria, but not in the West (40), even though Plotinus lived in Rome for a while. ${ }^{103}$ Pagan 'holy men', let alone

99 That is why D. Frankfurter, The Cult of the Martyrs in Egypt before Constantine: The Evidence of the Coptic Apocalypse of Elijah, in: Vigiliae Christianae 48, Issue 1, 1994, p. 25-47, is hardly persuasive.

100 But see S. I. Johnston, Sosipatra and the Theurgic Life: Eunapius Vitae Sophistorum 6.6.56.9.24, in: J. Rüpke (ed.), Reflections on Religious Individuality. Greco-Roman and Judaeo-Christian Texts and Practices (Religionsgeschichtliche Versuche und Vorarbeiten; 62), Berlin 2012, p. 99-117; I. Tanaseanu-Döbler, Sosipatra - Role Models for 'Divine' Women in Late Antiquity, in: M. Dzielska / K. Twardowska (ed.), Divine Men and Women in the History and Society of Late Hellenism (Byzantina et slavica cracoviensia; 7), Cracow 2013, p. 123-147; N. D. Lewis, Living Images of the Divine: Female Theurgists in Late Antiquity, in: K. B. Stratton / D. S. Kalleres (ed.), Daughters of Hecate. Women \& Magic in the Ancient World, Oxford 2014, p. 274-297.

101 Fowden, The Pagan Holy Man (Fn. 49). The numbers in the text refer to the relevant pages.

102 See especially C. Macris, Pythagore, un maître de sagesse charismatique de la fin de la période archaïque, in: G. Filoramo (ed.), Carisma profetico: fattore di innovazione religiosa (Le scienze umane, 2; 3), Brescia 2003, p. 243-289; G. Filoramo, Becoming Divine by Imitating Pythagoras?, in: Mètis NS 4, 2006, p. 297-329.

103 See also I. Tanaseanu-Döbler, Gibt es eine pagane communio sanctorum in der Spätantike? Personale und kollektive Heiligkeitsvorstellungen im spätantiken Heidentum, in: P. Gemeinhardt / K. Heyden (ed.), Heilige, Heiliges und Heiligkeit in spätantiken Religionskulturen (Religionsgeschichtliche Versuche und Vorarbeiten; 61), Berlin/Boston 2012, p. 327-368, here p. 341. For Plotinus as 'holy man', see M. J. Edwards, Birth, Death, and Divinity in Porphyry's Life of Plotinus, in: Th. Hägg / Ph. Rousseau (ed.), Greek Biography and Panegyric in Late Antiquity (The Transformation of the Classical Heritage; 31), Berkeley/Los Angeles/ London 2000, p. 52-71. 
'holy women', were not a phenomenon of Roman culture and this should be taken into account in our argument about the influence of pagan heroes on the making of Christian saints. Rome's religious culture was much more secular than that of Greece and lacked traditions about charismatic wonder-workers, such as Aristeas, Epimenides and Pythagoras, of whom we hear much in Archaic Greece. ${ }^{104}$ Yet we should not overstate the importance of these pagan 'holy men', as they rarely appear outside the philosophical texts in the works of pagan historians or rhetoricians. ${ }^{105}$ Moreover, their schools were not homogeneous and often became dispersed after the death of the teacher. ${ }^{106}$ Consequently, despite being pagan, these 'holy or 'divine' men (see below) did not function as centres of a cult for Late Antique paganism.

It is rather striking that, like Brown, Fowden never seems to worry about his terminology or feel the need to define the concept of 'holy man'.107 Yet 'holy man' is not a term used by our sources, although they use the term 'holy race' at the end of antiquity (34). In other words, it is an 'etic' term, not an 'emic' designation. I submit that this is not a useful term and we should avoid it where possible. Even if 'divine man' is not without problems either, as it is also not a technical 'emic' term, ${ }^{108}$ it is much more appropriate, since the pagans stressed the proximity of their 'divine men' to the gods and sometimes even noted their divinity (50). ${ }^{109}$ In Christianity, on the other hand, the 'holy men' saw themselves as followers and imitators of Christ ( $\$ 3$ and 5) but imitators who were unable to even begin to bridge the ontological gap between the human and the divine.

Yet these pagan 'divine men' did share something with the Christian saints and holy men, that is, a kind of hagiography. From the earlier third century AD onwards we have a whole series of biographies of pagan 'divine men', such as those of Apollonius of Tyana, Plotinus, Pythagoras, Proclus, Isidorus and Plato, to mention only the most well-known, which show similarities with the biographies of Moses, Jesus and the Christian saints. Having noted these similarities when working on Christian hagiography, Marc Van Uytfanghe has persuasively argued that we should no longer speak of a hagiographical genre but of a hagiographical dis-

104 H. Leppin, Zum Wandel des spätantiken Heidentums, in: Millennium 1, 2004, p. 59-81, here p. 80-81.

105 Tanaseanu-Döbler, Gibt es eine pagane communio sanctorum (Fn. 102), p. 343-344, but for a different opinion, see Leppin, Zum Wandel (Fn. 103), p. 73-74.

106 Tanaseanu-Döbler, Gibt es eine pagane communio sanctorum (Fn. 102), p. 351-367.

107 Ibid., p. 327 (with many excellent methodological considerations in her article).

108 See the objections of J.-J. Flinterman, The Ubiquitous 'Divine Man', in: Numen 43, Issue 1, 1996, p. 82-98; D. S. du Toit, Theios Anthropos. Zur Verwendung von theios anthropos und sinnverwandten Ausdrücken in der Literatur der Kaiserzeit (Wissenschaftliche Untersuchungen zum Neuen Testament, 2; 91), Tübingen 1997.

109 R. Goulet, Études sur les Vies de philosophes de l'Antiquité tardive. Diogène Laërce, Porphyre de Tyr, Eunape de Sardes (Textes et traditions; 1), Paris 2001, p. 44-51 (the whole chapter 'Les vies de philosophes de l'antiquité tardive', 3-63 is relevant for this section); Tanaseanu-Döbler, Gibt es eine pagane communio sanctorum (Fn. 102), p. 344-351. 
course. This can be found in both pagan and Christian biographies, epitaphs, hymns, letters, novels and sermons (I have already applied this idea to our martyrological texts above $[\S 3])$. According to Van Uytfanghe, ${ }^{110}$ we can identify four characteristics of this discourse:

1. The subjects are close to God, but not God or the gods themselves;

2. The discourse is rooted in oral tradition but borrows freely from historic and invented materials when written down;

3. It is more performative than informative;

4. It pictures the world in fixed terms according to which good and evil are clearly distinguishable.

It is important to realise that in our sources this discourse seems to start with Philo's "Life of Moses" and the Gospels. Subsequently, it can be found in Lucian, ${ }^{111}$ in the Apocryphal Acts of the Apostles of the late second century and, especially, in Philostratus' "Life of Apollonius of Tyana" and the "Lives of Pythagoras" by Porphyry and Iamblichus, who drew on earlier, now lost biographies, which probably contained a similar discourse. This discourse lasted until the end of antiquity for pagan 'hagiography' but it has continued in the Christian world up to the present day.

Evidently, there are differences between pagan and Christian discourse, as the latter stresses humility and the imitation of Christ, prefers more miracles and attaches more weight to the struggle against evil and the Devil. Yet there are also many similarities when we look at the miraculous births, precocious youth, asceticism, clairvoyance, miracles, piety, travels and extraordinary deaths of the pagan and Christian holy men. A certain amount of exchange is, it seems to me, important in the development of this discourse. Glen Bowersock has pointed to the influence of the Gospels, in particular the motif of the empty grave and the

110 M. Van Uytfanghe, Heiligenverehrung II (Hagiographie), in: E. Dassmann [et al.] (ed.), Vol. 14: Heilig - Hexe, Stuttgart 1988, p. 150-183; M. Van Uytfanghe, L'Hagiographie: un genre chrétien ou antique tardif?, in: Analecta Bollandiana 111, 1993, p. 135-188; M. Van Uytfanghe, Biographie II (spirituelle): A. Griechisch-römisch; B. Jüdisch; C. Christlich, in: T. Klauser [et al.] (ed.), Reallexikon für Antike und Christentum, Supplement 1: Aaron Biographie, Stuttgart 2001, p. 1088-1364; M. Van Uytfanghe, La biographie classique et l'hagiographie chrétienne antique tardive, in: Hagiographica 12, 2005, p. 223-248; M. Van Uytfanghe, La Vie d'Apollonius de Tyane et le discours hagiographique, in: K. Demoen / D. Praet (ed.), Theios Sophistes. Essays on Flavius Philostratus' Vita Apollonii (Mnemosyne, Supplementum; 305), Leiden 2009, p. 335-374; M. Van Uytfanghe, L'origine et les ingrédients du discours hagiographique, in: Sacris Erudiri 50, 2011, p. 35-70. There is a certain development in these articles which still needs to be charted and discussed. Note also the older but still useful study by L. Bieler, Theios Aner. Das Bild des 'Göttlichen Menschen' in Spätantike und Frühchristentum, 2 Vols., Vienna 1935-1936 [Repr. Darmstadt 1976].

111 For Lucian's knowledge of New Testament writings, see J. N. Bremmer, Richard Reitzenstein's Hellenistische Wundererzäblungen, in: T. Nicklas / J. Spittler (ed.), Credible, Incredible. The Miraculous in the Ancient Mediterranean (Wissenschaftliche Untersuchungen zum Neuen Testament; 321), Tübingen 2013, p. 1-19, here p. 4-5. 
resurrection, on the pagan Greek imagination. ${ }^{112}$ And whereas the Christian Apocryphal Acts contain many themes found in the pagan Greek novel, at least one pagan biography, that of Apollonius written by Philostratus, contains too many parallels with the Gospels for the latter not to have been of at least some influence. ${ }^{113}$ We should never forget that pagans and Christians lived in the same society and that, especially from the later second century - witness Celsus, Galen, Lucian, Numenius and Marcus Aurelius - the Christians had attracted the attention of pagan intellectuals. ${ }^{114}$

Fowden could not have been familiar with Van Uytfanghe's contributions when he wrote his study of the pagan 'holy man', but it is clear that the hagiographic discourse helped to construct an image of the pagan 'divine man' which did not always correspond to historical reality. However, in that respect, these images were not fundamentally different from what was constructed in the Christian world, to which we shall turn now.

\section{The Rise of the Saints}

After the end of the Christian persecutions around AD 260, there followed forty years of peace in which the Christian Church greatly increased its following. ${ }^{115}$ The sudden onset and harshness of Diocletian's persecutions must have come as a terrific shock, and the many victims of the persecutions, which lasted in some areas in the East until the early 320s, will have provided a powerful stimulus for the cult of the martyrs. Although the precise developments in East and West have not yet been satisfactorily charted, an important factor in this change may well have been the admiration of the emperor himself for the martyrs. From his oration (§3), it seems that he himself had witnessed martyrdoms and had admired the perseverance of the martyrs; indeed, we find a record of this in one of his letters which is quoted in Eusebius' "Life of Constantine" (2.51.2-52.1). ${ }^{116}$ The admiration soon translated itself into the construction of churches on top of the traditional Roman graves of Peter and Paul. ${ }^{117}$

112 G. Bowersock, Fiction as History: Nero to Julian (Sather Classical Lectures; 58), Berkeley/ Los Angeles/London 1994.

113 For many examples, see Van Uytfanghe, La Vie d'Apollonius de Tyane et le discours hagiographique (Fn. 109), p. 336-338.

114 Cf. G. Rinaldi, Biblia Gentium, Rome 1989; W. Kinzig, Pagans and the Bible, in: J. Carleton Paget / J. Schaper (ed.), The New Cambridge History of the Bible, Vol. 1: From the beginnings to 600, Cambridge 2013, p. 752-774.

115 This peace is well stressed by Barnes, Early Christian Hagiography (Fn. 74), p. 16-17.

116 Girardet, Konstantin, Rede an die Versammlung (Fn. 90), p. 84-87.

117 Baumeister, Martyrium (Fn. 65), p. 113-137 (“Konstantin der Große und die Märtyrer”), but note Diefenbach, Römische Erinnerungsäume (Fn. 84), p. 155-181, who stresses the importance of the imperial cult in these new churches. 
It is not surprising that other large cities now also wanted to have prestigious martyrs. Yet, for reasons that are not entirely clear, it was not until ca. AD 354 that the body of the martyr Babylas was installed close to the pagan oracle of Daphne in Antioch. Constantinople immediately followed suit and in 356 it 'imported' the body of Timothy, the friend of Paul, from Ephesus. ${ }^{118}$ The year after, the bodies of the Apostles Andrew and Luke arrived from Patras and Alexandria, respectively, and in the following decades the capital witnessed a stream of bodies, including not only martyrs but even that of the prophet Samuel. ${ }^{119}$ These transfers of martyrs' bodies must have happened very frequently for, in AD 386, an imperial law prohibited translations without an imperial licence (Codex Theod. 9.17.7). Moreover, from the middle of the century onwards, as attested by Hilary of Poitiers, we also hear of miracles happening at the graves of the martyrs, the reports of which were soon collected in small books and spread around to advertise the power of the local martyr. ${ }^{120}$

The irritation of the Emperor Julian (361-363: Contra Galilaeos 355C) at the new attention to the bodies of martyrs shows its success in the East but the West was considerably slower in showing the same degree of interest. Probably inspired by the efforts of Pope Damasus, it was only in AD 378, during a fierce struggle with the Arians, that Ambrosius organised the translation of the martyrs Protasius and Gervasius into the basilica of Milan. ${ }^{121}$ This innovative move soon

118 For a probable connection with the Acta S. Timothei, see C. Zamagni, Passion (ou Actes) de Timothée. Étude des traditions anciennes et édition de la forme BHG 1487, in: A. Frey and R. Gounelle (ed.), Poussières de christianisme et de judaïsme antiques: Etudes réunies en l'honneur de Jean-Daniel Kaestli et Eric Junod (Publications de l'Institut Romand des Sciences Bibliques; 5), Prahins 2007, p. 341-364.

119 Delehaye, Les origines (Fn. 6), p. 54-57; R. W. Burgess, The Passio S. Artemii, Philostorgius, and the Dates of the Invention and Translations of the Relics of Sts Andrew and Luke, in: Analecta Bollandiana 121, 2003, p. 5-36, repr. in R. W. Burgess, Chronicles, Consuls, and Coins: Historiography and History in the Later Roman Empire, Farnham/Burlington 2011, Ch. 11 (whose reconstruction of the year AD 336 seems to me hardly persuasive); J. Wortley, The Earliest Relic-importations to Constantinople, in: Wortley, Studies on the Cult of Relics in Byzantium up to 1204 (Variorum Collected Studies Series; 935), Franham/Burlington 2009, p. 207-225.

120 Van Uytfanghe, L'origine, l'essor (Fn. 15), p. 170-171; R. Wiśniewski, Suspended in the Air. On a Peculiar Case of Exorcism in Late Ancient Christian Literature, in: T. Derda [et al.] (ed.), Euergesias Charin. Studies Presented to Benedetto Bravo and Ewa Wipszycka (The Journal of Juristic Papyrology, Supplement; 1), Warsaw 2002, p. 363-380. Small books: H. Delehaye, Les premiers Libelli miraculorum, in: Analecta Bollandiana 29, 1910, p. 427434; H. Delehaye, Les recueils antiques de miracles de saints, in: Analecta Bollandiana 43, 1925, p. 5-85, 305-325; A.-J. Festugière, Collections grecques de miracles, Paris 1971; M. Heinzelmann, Une source de base de la littérature hagiographique latine: le recueil de miracles, in: Hagiographie, cultures et sociétés, IV ${ }^{\mathrm{e}}-\mathrm{XII}{ }^{\mathrm{e}}$ siècles, Paris 1981, p. 235-259; S. Efthymiadis, Collection of Miracles (Fifth-Fifteenth Centuries), in: S. Efthymiadis (ed.), The Ashgate Research Companion to Byzantine Hagiography, Farnham/Burlington 2014, Vol. 2, p. 103-142.

121 J. den Boeft, Milaan 386: Protasius en Gervasius, in: A. Hilhorst (ed.), De heiligenverering in de eerste eeuwen van het Christendom, Nimwegen 1988, p. 168-178; J. den Boeft, "Vetusta Saecla uidimus". Ambrose's hymn on Protasius and Gervasius, in: G. J. M. Bartelink 
promoted similar translations elsewhere in the West, which had considerably fewer martyrs than the East, although not immediately in Rome itself. ${ }^{122}$ At the end of the fourth century John Chrysostom can even boast about the beauty of the buildings housing the martyrs and of the frequency with which they were visited. ${ }^{123}$ Given that, as we have seen, pagan heroes were worshipped only in the East, I will now concentrate on this region, albeit not without paying some attention to parallel developments in the West. ${ }^{124}$

Unlike for the West, where we have little information about the evolving cult of the martyrs, we are quite well informed about the situation in the East through the writings of the so-called Cappadocian Fathers, Basil the Great of Caesarea (330379), his younger brother Gregory of Nyssa (ca. 332-395) and their close friend Gregory of Nazianzen (329-389), as well as the writing of their younger contemporary Asterius of Pontic Amasea (ca. 350-ca. 410). The Cappadocians all became bishops after the brief rule of Julian the Apostate, when several more martyrs had died for their faith. ${ }^{125}$ The date of their careers means that we have little information about the developments in the first decades after Constantine's victory, when the Christian Church must have made many gains already. However, from their letters and sermons we can build a fairly good picture of the cult of the martyrs in the last decades of the fourth century in Cappadocia and Pontus. ${ }^{126}$

[et al.] (ed.), Eulogia: Mélanges offerts à Antoon A. R. Bastiaensen à l'occasion de son soixante-cinquième anniversaire (Instrumenta Patristica; 24), The Hague 1991, p. 65-75. Note that the two saints ended up as the patron saints of Breisach am Rhein, near Freiburg: Unser Münster 50, 2014 (special issue dedicated to these saints).

122 A. Thacker, Popes, Patriarchs and Archbishops and the Origins of the Cult of the Martyrs in Northern Italy, in: P. Clarke / T. Claydon (ed.), Saints and Sanctity (Studies in Church History; 47), Woodbridge 2011, p. 51-79. For Rome, see Diefenbach, Römische Erinnerungsräume (Fn. 84), p. 360-379.

123 Chrysostom, In Epistolam II ad Corinthos 26.5 (= Patrologia Graeca [henceforth: PG] 61.582).

124 For a good survey of the history and important aspects of the Acta martyrum in the East, see M. Detoraki, Greek Passions of the Martyrs in Byzantium, in: Efthymiadis, The Ashgate Research Companion to Byzantine Hagiography (Fn. 120), p. 61-101.

125 For their limited number, see H. C. Teitler, Avenging Julian. Violence against Christians during the Years 361-363, in: A.-C. Geljon / R. Roukema (ed.), Violence in Ancient Christianity: Victims and Perpetrators (Vigiliae Christianae, Supplements; 125), Leiden 2014, p. 76-89 (with older bibliography) and H. C. Teitler, The Last Pagan Emperor. Julian the Apostate and the War against Christianity, New York 2017, but see also H. C. Brennecke, Studien zur Geschichte der Homöer. Der Osten bis zum Ende der homöischen Reichskirche (Beiträge zur historischen Theologie; 73), Tübingen 1988, p. 87-157.

126 Cf. M. Girardi, Basilio di Cesarea e il culto dei martiri nel IV secolo. Scrittura e tradizione (Vetera Christianorum, Quaderni; 21), Bari 1990, p. 147-233; J. Leemans, Celebrating the Martyrs: Early Christian Liturgy and the Martyr Cult in Fourth Century Cappadocia and Pontus, in: Questions Liturgiques 82, 2001, p. 247-267; S. Métivier, La Cappadoce (IVe$\mathrm{VI}^{\mathrm{e}}$ siècle). Une histoire provinciale de l'Empire romain d'Orient (Publications de la Sorbonne, Série Byzantina Sorbonensia; 22), Paris 2005, p. 305-309; B. Bitton-Ashkelony, Encountering the Sacred: The Debate on Christian Pilgrimage in Late Antiquity (The Transformation of the Classical Heritage; 38), Berkeley/Los Angeles/London 2005, p. 33-44; 
To celebrate the festival of the anniversary of the death of the martyr, the faithful gathered once a year at the small sanctuary that contained the martyr's body, the martyrion. This was initially situated at the edge of the towns but later, and in much larger sizes, could often be found in the centre of metropoleis such as Antioch and Constantinople, ${ }^{127}$ just as was the case with the earlier hero cults (§ 1). The Greek name of the festival, panegyris, actually means 'fair', and a fair was a standing part of pagan festivals, such as the Eleusinian Mysteries. ${ }^{128}$ There is a clear continuity here with the pagan past, and the fact that the worshippers usually arrived in a procession at the martyrion also suggests that, when celebrating, the newly converted Christians brought along their old festival habits, as Christianity was still devising its own celebratory culture. During the festival, which could last several days, there was a vigil and people sang psalms, celebrated the Eucharist, conducted business, and generally had a good time. Some girls, albeit surely only occasionally, even performed lewd dances, to the indignation of Bishop Basil. ${ }^{22}$ But for our purpose the most important moment was the sermon by the bishop in which he remembered and praised the martyr.

In his sermon the bishop usually, but certainly not always, related the story of the life and death of the martyr, male or female, and interspersed his biography with exhortations to follow the martyr's example: imitatio martyris but, of course, based on the imitatio Christi. The bishop also used his sermons to impress upon his audience the ideal of an ascetic lifestyle, thus foreshadowing the idea of the ascetic as a holy man. Following the example of the martyr, the audience was enjoined to display courage in order to be able to despise the world. ${ }^{130}$ But the

V. Limberis, Architects of Piety. The Cappadocian Fathers and the Cult of the Martyrs, Oxford 2011.

127 See still A. Grabar, Martyrium, 3 Vols., Paris 1943-1946 and A. Grabar, Martyrium ou 'vingt ans après', in: Cahiers archéologiques 18, 1968, p. 239-244; S. de Blaauw, Kultgebäude, in: G. Schöllgen [et al.] (ed.), Reallexikon für Antike und Christentum, Vol. 20: Krieg Lexikon 1, Stuttgart 2008, p. 227-393, here p. 316-336; A. M. Yasin, Saints and Church Spaces in the Late Antique Mediterranean. Architecture, Cult, and Community, Cambridge 2009; Limberis, Architects of Piety (Fn. 123), p. 68-96 (with informative illustrations).

128 L. de Ligt / P. W. de Neeve, Ancient Periodic Markets: Festivals and Fairs, in: Athenaeum 66, 1988, p. 391-416; M. Wörrle, Stadt und Fest im kaiserzeitlichen Kleinasien. Studien zu einer agonistischen Stiftung aus Oinoanda (Vestigia; 39), Munich 1988, p. 209-215; C. Chandezon, Foires et panégyries dans le monde grec classique et hellénistique, in: Revue des Études Grecques 113, 2000, p. 70-100; R. Basser, Is the Pagan Fair Fairly Dangerous? Jewish-Pagan Relations in Antiquity, in: L. E. Vaage (ed.), Religious Rivalries in the Early Roman Empire and the Rise of Christianity (Studies in Christianity and Judaism; 18), Waterloo, Ont. 2006, p. 73-84; Y. Cohn, The Graeco-Roman Trade Fair and the Rabbis, in: Journal of the American Oriental Society 131, Issue 2, 2011, p. 187-193.

129 Basil, Homily on Drunk People 1 (= PG 31.445). For such dances, see Gemeinhardt, Die Kirche und ihre Heiligen (Fn. 64), p. 275-276. In general: P. Brown, Enjoying the Saints in Late Antiquity, in: Early Medieval Europe 9, 2000, p. 1-24; M. Kahlos, Comissationes et ebrietates Church leaders against banqueting at martyria and at tombs, in: O. Merisalo and R. Vainio (ed.), Ad itum liberum. Essays in honour of Anne Helttula, Jyväskylä 2007, p. 13-23.

130 P. Brown, The Saint as Exemplar in Late Antiquity, in: Representations 2, 1983, p. 1-25. For examples from Asterius and John Chrysostom, see J. Leemans, Flexible Heiligkeit. Der 
propagation of this message was not confined to words. From various sermons we learn that the walls of the martyria were adorned with paintings of the life and death of the martyr. ${ }^{131}$ Evidently, while the clergy tried to impress the lay people, the latter will have enjoyed their festivals anyway, given the astounding popularity of martyr cults in the late fourth century. With the gradual disappearance of pagan festivals, these cults must have been an important compensation for the human need for leisure and pleasure, since early Christianity originally celebrated only a small number of festivals: mainly Easter, Pentecost and Epiphany. At the same time, the martyrs filled the void left by the disappearance of the pagan pantheon with its gods and heroes. God and Christ were far away but the martyr was your local friend and protector.

The huge success of the martyr cult meant that demand soon outstripped supply: there simply were not enough martyrs available to fulfil all the desires for local martyr heroes, as is noted by Augustine in the West. The same situation must have originally prevailed in the East as well, where relatively few homilies on martyrs have survived; 132 even Gregory the Great still complained about the pauca collecta. ${ }^{133}$ This problem served as a motivation for body snatchers and relic hunters and Augustine can be found condemning monks for selling the body parts of martyrs. ${ }^{134}$ But even if there was the body of a martyr, there still needed to be a biography and martyrdom, as not a day passed in the course of the year without martyrs being crowned somewhere, as Augustine complains. ${ }^{135}$ This statement might seem rather exaggerated but Chrysostom (Hom 1 in Rom $=$ PG 60.391) also mentions that martyrs were regularly celebrated in Antioch twice a week. The problem could be partially solved by allowing the clergy to read the Acta martyrum in the official liturgy, as happened in North Africa but not in Rome or in the East. ${ }^{136}$

Beitrag der Märtyrer zur Identitätskonstitution christlicher Gemeinden im griechischen Osten im 4. Jahrhundert, in: Gemeinhardt / Heyden, Heilige, Heiliges und Heiligkeit (Fn. 103), p. 217-220.

131 Cf. J. Leemans, 'Schoolrooms for Our Souls'. The Cult of the Martyrs: Homilies and Visual Representations as a Locus for Religious Education in Late Antiquity, in: Paedagogica Historica 36, Issue 1, 2000, p. 112-127; Limberis, Architects of Piety (Fn. 123), p. 55-62. For a painting of his martyrdom above the tomb of the Roman martyr Hippolytus, who died ca. 235 AD, note Prudentius, Peristephanon 11, cf. I. Fielding, Elegiac Memorial and the Martyr as Medium in Prudentius' Peristephanon, in: Classical Quarterly 64, Issue 2, 2014, p. 808-820, here p. 814-815.

132 Augustine, Sermo 315.1; C. Datema, De homileet en de heilige, in: A. Hilhorst (ed.), De heiligenverering in de eerste eeuwen van het Christendom, Nijmwegen 1988, p. 105-113.

133 Gregorius Magnus, Registrum Epistolarum 8.28.

134 Augustine, De opere monachorum 36, cf. L.Th. Lefort, La chasse aux reliques des martyrs en Égypte au IV siècle, in: La Nouvelle Clio 6, 1954, p. 225-230; S. Lafferty, Ad sanctitatem mortuorum: Tomb Raiders, Body Snatchers and Relic Hunters in Late Antiquity, in: Early Medieval Europe 22, Issue 3, 2014, p. 249-279.

135 Augustine, Sermones, Denis, 13.1.

136 Concilium Hipponense c. 36 (Africa); B. de Gaiffier, La lecture des passions des martyrs à Rome avant le IX ${ }^{\mathrm{e}}$ siècle, in: Analecta Bollandiana 87, 1969, p. 63-78. It may have played a role that there are no "Acta" known for Rome, unlike of course North Africa. 
One approach was the translation of Greek Passiones into Latin ${ }^{137}$ but another, more popular, way of solving the problem was to fill in the life of martyrs about whom little was known at all, beyond, perhaps, the name and the time of the martyrdom. Most radically, the need could be satisfied by simply inventing new martyrs. The accounts of the latter martyrdoms are the so-called passions épiques, as Delehaye named them, which usually delighted in gory details and made the Roman persecutor crueller and the martyr more heroic than they had often been in reality. 138

The enormous prestige of the martyrs meant that some bishops now promoted the cult of 'bloodless' martyrs as well. We see this first in the "Life of Antony" by Athanasius (ca. AD 356) and in Gregory of Nyssa's biography, in the form of a letter, of his sister Macrina (AD 380). Both Gregory and the Alexandrian bishop tried to assimilate their protagonists as much as possible to the martyrs, even though they had not died for their faith. After the persecutions had ceased, Antony returned to his cell to practice a severe asceticism, which Athanasius describes as follows: 'there he was daily a martyr to his conscience, fighting in the battles of the faith' (47), and these conflicts were his heroic struggles with the Devil and demons. Interestingly, in his "Life" Athanasius copied some parts of a biography of Pythagoras - a good example of the interdependence of pagan and Christian hagiographical discourse. ${ }^{139}$ As regards Macrina, before Gregory visited his dying sister after an interval of 8 years, he had a vision three times during the same night in which he, as he says, 'seemed to be carrying the relics of martyrs in my hand' (15). He described her funeral as a martyr's festival and she was laid to rest in the 'House of the Holy Martyrs' (33-34), the family martyrion; yet Gregory also stresses Macrina's ascetic life. ${ }^{140}$ Athanasius even states

137 M. Van Uytfanghe, L'hagiographie en Occident de la Vita Antonii aux Dialogues de Grégoire le Grand: genèse et occupation du terrain, in: A. Degl'Innocenti [et al.] (ed.), Gregorio Magno e l'agiografia fra IV et VII secolo (Archivum Gregorianum; 12), Florence 2007, p. 3-51, here p. 6-8.

138 H. Delehaye, Les Passions des martyrs et les genres littéraires, Brussels 1921 [ $\left.{ }^{2} 1966\right]$; see also I. Opelt, Paradeigmata Poetica Christiana. Untersuchung zur christlichen lateinischen Dichtung (Kultur und Erkenntnis; 3), Düsseldorf 1988, p. 26-40; Van Minnen, Saving History? (Fn. 68), passim; Van Uytfanghe, L'hagiographie en Occident (Fn. 134), p. 13-20; C. Lanéry, Hagiographie d'Italie (300-550), I: Les passions latines composées en Italie, in: G. Philippart (ed.), Hagiographies, Vol. 5, Turnhout 2010, p. 15-369, here p. 68-80.

139 See J. N. Bremmer, Richard Reitzenstein, Pythagoras and the Life of Antony, in: A.-B. Renger and A. Stavru (ed.), Forms and Transformations of Pythagorean Knowledge, Wiesbaden 2016, p. 227-245; for other examples of this mutual influence, see Van Uytfanghe, Biographie II (Fn. 109), p. 1336-1341.

140 Cf. A. van Loveren, Once again: "the Monk and the Martyr": St Anthony and St Macrina, in: Studia Patristica 17, Issue 2, 1982, p. 528-538; M. Alexandre, Les nouveaux martyrs. Motifs martyrologiques dans la vie des saints et thèmes hagiographiques dans l'Éloge des martyrs chez Grégoire de Nysse, in: A. Spira (ed.), The Biographical Works of Gregory of Nyssa (Patristic Monograph Series; 12), Cambridge, MA 1984, p. 33-70; Gemeinhardt, Die Kirche und ihre Heiligen (Fn. 64), p. 327-360. Still useful: M. Viller, Le martyre et l'ascèse, in: Revue d'Ascétique et de Mystique 6, 1925, p. 105-142; E. Malone, The Monk and the 
that Antony would have liked to be a martyr but did not succeed in becoming one, just as Sulpicius Severus felt obliged to mention this of his hero Martin of Tours: both are martyrs manqués. ${ }^{141}$

It is remarkable how these authors stress the strenuous ascetic efforts of their protagonists. With the receding of the reality of the persecutions, 'symbolic' martyrdom became now more important. The "Life of Antony" had an enormous impact, especially in the West, much more than initially in Egypt itself, ${ }^{142}$ and it was now the ascetics that started to come to the fore, the famous 'holy men' of Peter Brown, although soon bishops would be included as well. ${ }^{143}$ The "Life of Antony" inspired Jerome to write a number of largely fictitious biographies which would help to promote the ascetic ideal. With the extension of the title 'holy' to non-martyrs we have reached a stage which can be called the beginning of individual sainthood. Dame Averil Cameron has argued that Peter Brown rightly avoided the term 'saint' in his famous article on the 'holy man', as 'in this early period there were no formal processes of sanctification, and no official bestowal of sainthood'. ${ }^{144}$ This seems unduly formalistic as it would exclude the many saints from the earlier Middle Ages and the Byzantine era. ${ }^{145}$

Yet we should realise that the rise of the real 'saint X or Y' was exceedingly slow. In the East, it is not before the later decades of the fourth century that Gregory of Nyssa calls Stephen, whom he also calls the protomartyr, 146 'the holy man' (Stephen 1 = PG 46.721B) and mentions the 'holy XL (= the forty martyrs of Sebaste)' (765B). Gregory of Nazianzen mentions 'the holy (martyr) Orestes' ( $P G$ 36.872) and the 'holy Basil' in his funeral oration of AD 381 for his friend, but these occurrences are still rare; in fact, John Chrysostom still avoids it in his

Martyr. The Monk as the Successor of the Martyr (Studies in Christian Antiquity; 12), Washington, D.C. 1950.

141 Athanasius, Vita Antonii 46.2, 6; Sulpicius Severus, Ep.2.8-11 (Martin is now in heaven martyribus adgregatus); Gemeinhardt, Die Kirche und ihre Heiligen (Fn. 64), p. 145.

142 For this surprising observation, see M. Choat, The Life of Antony in Egypt, in: B. Leyerle / R. D. Young (ed.), Ascetic Culture. Essays in Honor of Philip Rousseau, Notre Dame, IN 2013, p. 50-74.

143 Baumeister, Heiligenverehrung I (Fn. 15), p. 141-143.

144 A. Cameron, On Defining the Holy Man, in: J. Howard-Johnston / P. A. Hayward (ed.), The Cult of Saints in Late Antiquity and the Middle Ages. Essays on the Contribution of Peter Brown, Oxford 1999, p. 27-43, here p. 27.

145 For the bibliography on canonisation, see Gemeinhardt, Die Kirche und ihre Heiligen (Fn. 64), p. 178.

146 Gregory of Nyssa, Second Homily on St. Stephen (PG 46.725B), cf. Bowersock, Martyrdom and Rome (Fn. 65), p. 75-76; F. Bovon, The Dossier on Stephen, The First Martyr, in: The Harvard Theololgical Review 96, Issue 3, 2003, p. 279-315; Grig, Making Martyrs (Fn. 74), p. 94-102; F. Bovon / B. Bouvier, La Révélation d'Étienne ou l'Invention des reliques d'Étienne, le saint premier martyr (Sinaiticus Graecus 493), in: A. Frey / R. Gounelle (ed.), Poussières de christianisme et de judaïsme antiques (Publications de l'Institut Romand des Sciences Bibliques; 5), Lausanne 2007, p. 79-105; F. Bovon / B. Bouvier, La translation des reliques de saint Étienne le premier martyr, in: Analecta Bollandiana 131, 2013, p. 5-50. 
huge oeuvre. In Egypt, there seem to be no examples in the documentary papyri before the sixth century. Not even in the most famous biography of an early saint, Athanasius' "Life of Antony", is the hermit called 'the holy Antony'; only the martyrs are hagioi (46). ${ }^{147}$

In the West the development is equally slow. In the fourth century, martyrs are usually still referred to in the plural in North Africa and even Pope Damasus (AD 366-384), who invested so much in the cult of the martyrs, ${ }^{148}$ uses the expression 'sanctus X' only rarely. Augustine never uses it, Ambrose uses the terminology more often and Jerome reserves it for pious women: sancta Melanium (Ep. 39.5.4) and sancta Marcella (Ep. 54.18.1). ${ }^{149}$ Although Roman inscriptions are often undated or hard to date, they too seem to mention the combination sanctus martyr only after Cyprian and not before the fourth century, ${ }^{150}$ which around AD 400 culminates in expressions such as sanctus Clemens or Sancta Eugenia. ${ }^{151}$ It is, I submit, the increasing expansion of the cult of the martyrs in the metropoleis that caused people to start identifying them individually. We can see, then, in the last decades of the fourth century the coming together of a number of factors: the expansion in numbers of martyrs, the expansion of the term 'saint' beyond martyrs and the individualisation of these holy persons by calling them 'saint $\mathrm{X}$ or Y'. It is only from this period onwards that we can really start speaking of Christian saints.

\section{From Heroes to Saints?}

It is time to draw some conclusions. Around 1900 the older German Forschung pushed the theme of continuity, driven as it was by an anti-Roman Catholic agenda, but the Bollandist Delehaye, as we saw, fiercely combated these views on the grounds that they undermined the beliefs of the Roman Catholic Church.

147 A. Papaconstantinou, Le culte des saints en Égypte des Byzantins aux Abassides, Paris 2001, p. 240-245; A. Papaconstantinou, The Cult of Saints: A Haven of Continuity in a Changing World, in: R. Bagnall (ed.), Egypt in the Byzantine World, 300-700, Cambridge 2007, p. 350-367, here p. 356. I am much indebted to Malcolm Choat for a discussion of this topic.

148 M. Sághy, Scinditur in partes populus: Pope Damasus and the Martyrs of Rome, in: Early Medieval Europe 9, Issue 3, 2000, p. 273-287; Grig, Making Martyrs (Fn. 74), p. 127-134; M. Sághy, Renovatio memoriae: Pope Damasus and the Martyrs of Rome, in: R. Behrwald / C. Witschel (ed.), Rom in der Spätantike, Stuttgart 2012, 251-265; D. Trout, Damasus of Rome: the Epigraphic Poetry, Oxford 2015.

149 Damasus: A. A. R. Bastiaensen, Le désignation du martyr dans le Sacramentaire de Vérone, in: Bastiaensen, Fructus centesimus (Fn. 54), p. 17-36. Ambrose: Delehaye, Sanctus (Fn. 56), p. 52-53. For Damasus and Ambrosius, see also M. Löx, Monumenta sanctorum, Wiesbaden 2013.

150 For some early examples, see Y. Duval, Auprès des saints corps et âme. L'inhumation 'ad sanctos' dans la chrétienté d'Orient et d'Occident du III au IV e siècle, Paris 1988, p. 134, 185-186; Pietri, Christiana Respublica (Fn. 10), p. 1269.

151 Still indispensable for this development, Delehaye, Sanctus (Fn. 56), p. 24-59. 
About a century later we find the dismissal of the theme of continuity by ancient historians but we can also observe a more favourable reception of the idea in several contributors to the "Reallexikon für Antike und Christentum". ${ }^{152}$ Indeed, it is perhaps possible in our time to look at the theme from a somewhat more distant perspective.

In this paper I have noted that the period from AD 150 until Constantine saw a martyrological discourse but not yet a full-fledged cult of the martyrs. The growth of such a cult during and after the rule of Constantine was concomitant with the development of a Christian hagiographical discourse. Looking back at the most important characteristics of the cult of the martyrs/saints, we cannot but notice significant differences between Greek heroes and Christian saints. First, pagan heroes, although often receiving a cult, are never called 'holy' or 'saint'. This is an important, albeit often ignored, difference between Christians and their non-Christian contemporaries and ancestors. Moreover, however important martyrs were, they remained fully human, unlike some heroes who could also be seen as gods, such as Heracles and Achilles. And unlike martyrs, heroes did not intervene with Zeus or other gods for the benefit of their worshippers. In a sermon in honour of the martyr Mamas, Basil the Great encouraged his audience to try to remember how often Mamas had appeared to them in a dream, how much support they received from him, how many sick people he cured, travellers he protected and dead children he resurrected. ${ }^{153}$ It would be hard to find a single Greek hero to whom we could ascribe all these feats. In other words, many a martyr may well have been represented as more powerful than was the case with most pagan heroes.

On the other hand, there are also similarities. Both saints and heroes had a clear local position, their graves were marked by sanctuaries and both were the focus of worship. As was the case with heroes such as Asclepius, martyrs were ascribed healing capacities. This can be seen in the "Apocryphal Acts of Thomas", dating to about AD 220, where the dust of the grave of the apostle heals the son of the king (170), although the passage may have been a later addition. As with heroes such as Theseus or Oedipus, their graves could protect the city, ${ }^{154}$ and, like Ajax or the Dioscures, ${ }^{155}$ they could also help in battle. This latter ability can

152 Baumeister, Heiligenverehrung I (Fn. 15), p. 103-105; Speyer, Heros (Fn. 4), p. 870-875; Van Uytfanghe, L'origine, l'essor (Fn. 15), p. 179-182.

153 Basil, On Mamas $1=$ PG 31.589. For the importance of Mamas in Cappadocia, see Métivier, La Cappadoce (Fn. 123), p. 312.

154 A. M. Orselli, L'idea e il culto del santo patron cittadino nella letteratura latina Cristiana, Bologna 1965, p. 91-96; for intervention by a martyr on behalf of Constantinople around AD 400, see C. Datema, The Rôle of the Martyr in the Homilies of Severian of Gabala, in: Bastiaensen, Fructus centesimus (Fn. 54), p. 61-67.

155 A. van den Hoek / J. J. Herrmann Jr., Pottery, Pavements, and Paradise. Iconographic and Textual Studies on Late Antiquity (Vigiliae Christianae, Supplements; 122), Leiden 2013, p. 296-297 persuasively suggest that the Dioscures "may have remained as subtext for pairings of Christian saints. It has a certain plausibility to consider saints such as Cosmas 
be seen particularly clearly in the later St George, whose legends originated in Cappadocia before the end of the fourth century. ${ }^{156}$ The iconography of some saints, in particular of military saints, displays them as warrior knights and seems to derive from the iconography of Greek heroes such as Bellerophon. ${ }^{157}$ We may even wonder if the military nature of the older Greek heroes did not have an impact on the popularity of military saints, which was so typical of the East. ${ }^{158}$ Last but not least, pagans and Christians shared a hagiographical discourse in order to construct and remember their 'holy' and 'divine' men.

In the end, though, our harvest of similarities is not that impressive. Smoking guns have not been found and there is no straight line from heroes to saints. Given that the West did not know cultic heroes, it is perhaps not surprising that the most persuasive similarities were found in the East. Here the early Christians could see bêrôa as models for their martyrs' graves and the iconography of their military saints. The Cappadocian Fathers and their younger contemporaries were still steeped in classical culture. It is thus perfectly possible, perhaps even probable, that the traditions of heroes inspired them to promote the functions of saints as healers, patrons of cities and saviours in wars and other catastrophes. The close contacts between East and West soon meant that local traditions were exported and appropriated everywhere in the Empire. Thus, in the end, the pagan Greek heroes probably did exert a moderate influence on the rise to sainthood of those ancient Christian heroes, the martyrs and ascetics.

and Damian, Sergius and Bacchus, Gervasius and Protasius, and even Peter and Paul, as transformations of the divine twins."

156 Bremmer, Greek Religion and Culture (Fn. 30); D. Woods, The Origin of the Cult of St George, in: D. V. Twomey / M. Humphries (ed.), The Great Persecution (Irish Theological Quarterly Monograph Series; 4), Dublin 2009, p. 141-158; Barnes, Early Christian Hagiography (Fn. 74), p. 318-321.

157 C. Belting-Ihm, Heiligenbild, in: E. Dassmann [et al.] (ed.), Reallexikon für Antike und Christentum, Vol. 14: Heilig - Hexe, Stuttgart 1988, p. 66-96, here p. 89-92.

158 H. Delehaye, Les Légendes grecques des Saints militaires, Paris 1909; A. M. Orselli, Santità militare e culto dei santi militari nell'impero dei Romani (secoli 6-10), Bologna 1993; C. Walter, The Warrior Saints in Byzantine Art and Tradition, Aldershot 2003; M. Grünbart, Vom christlichen Soldaten zum kriegerheiligen: Die Militarisierung der Märtyrer von der Spätantike bis in die byzantinische Zeit, in: E. Haustein-Bartsch (ed.), Von Drachenkämpfern und anderen Helden. Kriegerheilige auf Ikonen, Recklinghausen 2016, p. 15-24. 